\title{
Acute and Chronic Nicotine Exposures Differentially Affect Central Serotonin 2A Receptor Function: Focus on the Lateral Habenula
}

\author{
Cristiano Bombardi ${ }^{1,+}+{ }^{\circ}$, Francis Delicata ${ }^{2,+}+{ }^{\circ}$, Claudio Tagliavia ${ }^{1}$, Massimo Pierucci ${ }^{2}$, \\ Gabriele Deidda ${ }^{2}$, Maurizio Casarrubea ${ }^{3}{ }^{\circledR}$, Philippe De Deurwaerdère ${ }^{4}$ and \\ Giuseppe Di Giovanni ${ }^{2,5, *(1)}$
}

1 Dipartimento di Scienze Mediche Veterinarie, Università di Bologna, Bologna, Via Tolara di Sopra, 50, 40064 Ozzano dell’Emilia (BO), Italy; cristiano.bombardi@unibo.it (C.B.); claudio.tagliavia2@unibo.it (C.T.)

2 Department of Physiology and Biochemistry, Laboratory of Neurophysiology, Faculty of Medicine and Surgery, University of Malta, MSD2080 Msida, Malta; francis.delicata.06@um.edu.mt (F.D.);

Massimo.pierucci@um.edu.mt (M.P.); gabriele.deidda@um.edu.mt (G.D.)

3 Department of Biomedicine, Neuroscience and Advances Diagnosis (BIND), Human Physiology Section "Giuseppe Pagano", Laboratory of Behavioral Physiology, University of Palermo, Viale delle Scienze n. 13, 90128 Palermo, Italy; maurizio.casarrubea@unipa.it

4 Centre National de la Recherche Scientifique (Unité Mixte de Recherche 5287), 146 rue Léo Saignat, B.P.281, F-33000 Bordeaux Cedex, France; philippe.de-deurwaerdere@u-bordeaux.fr

5 School of Biosciences, Cardiff University, Cardiff CF10 3AX, UK

* Correspondence: giuseppe.digiovanni@um.edu.mt or digiovannig@cardiff.ac.uk; Tel.: +356-234-027-76

+ These authors contributed equally to this work.

Received: 3 February 2020; Accepted: 6 March 2020; Published: 9 March 2020

check for updates

\begin{abstract}
Nicotine addiction is a serious public health problem causing millions of deaths worldwide. Serotonin (5-hydroxytryptamine; 5-HT) is involved in central nervous system (CNS) nicotine effects, and it has been suggested as a promising pharmacological target for smoking cessation. In this regard, what is particularly interesting are the $5-\mathrm{HT}_{2 \mathrm{~A}}$ receptors $\left(5-\mathrm{HT}_{2 \mathrm{~A}} \mathrm{Rs}\right)$ and the lateral habenula $(\mathrm{LHb})$, a central area in nicotine addiction that we showed to be under a strong $5-\mathrm{HT}_{2 \mathrm{~A}} \mathrm{R}-$ modulation. Single-cell extracellular recording of $\mathrm{LHb}$ neurons was used to study the $5-\mathrm{HT}_{2 \mathrm{~A}} \mathrm{R}$ function by intravenously administrating the potent agonist TCB-2. Acute nicotine $(2 \mathrm{mg} / \mathrm{kg}$, intraperitoneal, i.p.) and chronic nicotine ( $6 \mathrm{mg} / \mathrm{kg} /$ day for 14 days) differently affected both the $5-\mathrm{HT}_{2 \mathrm{~A}} \mathrm{R}$-immuno reactive (IR) neuron number and the $5-\mathrm{HT}_{2 \mathrm{~A}} \mathrm{R}$ immunostaining area in the different brain areas studied. After acute nicotine, TCB-2 cumulative doses (5-640 $\mu \mathrm{g} / \mathrm{kg}$, intravenous, i.v.) bidirectionally affected the activity of $74 \%$ of $\mathrm{LHb}$ recorded neurons. After chronic nicotine treatment, TCB-2 was only capable of decreasing the $\mathrm{LHb}$ firing rate. The expression of $5-\mathrm{HT}_{2 \mathrm{~A}} \mathrm{R}$ under acute and chronic nicotine exposure was studied in the $\mathrm{LHb}$ and in other brain areas involved in nicotine effects in rats by using immunohistochemistry. These data reveal that acute and chronic nicotine differentially affect the $5-\mathrm{HT}_{2 \mathrm{~A}} \mathrm{R}$ function in different brain areas and this might be relevant in nicotine addiction and its treatment.
\end{abstract}

Keywords: 5- $\mathrm{HT}_{2 \mathrm{C}} \mathrm{R}$; nucleus accumbens; dorsal raphe nucleus; addiction; depression; medial prefrontal cortex; dentate gyrus; striatum; ventral tegmental area; substantia nigra pars compacta

\section{Introduction}

Cigarette smoking is one of the most common addictions that is decreasing in Western societies, but dramatically increasing in third world countries [1]. Cigarette smoke is the primary avoidable cause 
of disability and death from several pathologies related to different organs, mainly respiratory and cardiovascular systems [2-4]. Considering that about 8 million people die every year as a consequence of nicotine addiction, smoking is among the most significant threat to world health. Nicotine, the primary molecule contained in tobacco leaves, and responsible in the development of addiction [5-7], is an exogenous agonist of the nicotinic cholinergic receptors (nAChRs). The addictive properties of this alkaloid depends primarily on the activation of the dopamine (DA) mesolimbic DA system [8,9], although, nicotine is known to affect many other neurotransmitters in the central nervous system (CNS), such as glutamate (GLU) [10], nitric oxide [11], gamma-aminobutyric acid (GABA) [12], and serotonin (5-hydroxytryptamine; 5-HT) [4,13]. Moreover, 5-HT and its receptors may be a key to tobacco addiction. Extensive and compelling animal and human data have recently revealed an essential interaction between nicotine and $5-\mathrm{HT}_{2 \mathrm{C}}$ receptors $\left(5-\mathrm{HT}_{2 \mathrm{C}} \mathrm{Rs}\right)$ that might open new therapeutic avenues to smoking cessation [14-17]. On the other hand, the 5- $\mathrm{HT}_{2 \mathrm{~A}}$ Rs have been less investigated, although it is known that the $5-\mathrm{HT}_{2 \mathrm{~A}} \mathrm{R}$ exerts a distinct role compared to $5-\mathrm{HT}_{2 \mathrm{C}} \mathrm{Rs}$ concerning the regulation of midbrain DA neurons [18,19], ultimately leading to an opposite influence of the two 5-HTRs in nicotine addiction. Indeed, their blockade is able to counteract nicotine self-administration, reinstatement, sensitization, conditioned hyperactivity, and withdrawal behaviors $[17,20,21]$. Even if 5- $\mathrm{HT}_{2 \mathrm{~A}}$ Rs are expressed in brain areas involved in nicotine addiction [22,23], the effect of nicotine on their expression has not yet been thoroughly investigated. The only evidence comes from an autoradiographic study showing that acute nicotine increased $\left[{ }^{3} \mathrm{H}\right]$ ketanserin binding to $5-\mathrm{HT}_{2 \mathrm{~A}} \mathrm{Rs}$ in the claustrum and ventral tegmental area (VTA) while short chronic (five days) nicotine treatment increased them also in the medial prefrontal cortex (mPFC), dorsal striatum (ST), shell of the nucleus accumbens (NAc) - but not in the claustrum [24].

Of particular interest in studying drug addiction is the lateral habenula $(\mathrm{LHb})$, a small epithalamic structure that conveys negative motivational signals [25], which might be an essential hub in nicotine/5- $\mathrm{HT}_{2 \mathrm{~A}} \mathrm{R}$ interaction. Indeed, the $\mathrm{LHb}$ can be directly activated by nicotine [26-28], and its lesion prevented nicotine-induce anxiety [29]. The $\mathrm{LHb}$ is heavily modulated by the serotonergic system and expresses several 5-HTR subtypes [30,31]. Of note, the $5-\mathrm{HT}_{2 \mathrm{~A}} \mathrm{R}$ seems to be one of the most critical 5-HTRs in modulating $\mathrm{LHb}$ neuronal activity also in comparison to $5-\mathrm{HT}_{2 \mathrm{C}} \mathrm{Rs}$. Nevertheless, the effect of acute and chronic nicotine on anatomical distribution of the $5-\mathrm{HT}_{2 \mathrm{~A}} \mathrm{R}$ protein in $\mathrm{LHb}$ and many other brain areas related to nicotine addiction remains obscure. Moreover, it is not known if nicotine treatment can change the $5-\mathrm{HT}_{2 \mathrm{~A}} \mathrm{R}$ modulation of the electrical activity of the target brain areas.

In the present study, to fill this gap, we studied the effect of the intraperitoneal (i.p.) administration of acute and chronic nicotine $\left(2 \mathrm{mg} / \mathrm{kg}\right.$ and $6 \mathrm{mg} / \mathrm{kg} /$ day for 14 days, respectively) on the $5-\mathrm{HT}_{2 \mathrm{~A}} \mathrm{R}$ protein expression in the $\mathrm{LHb}$. To study whether plastic functional changes of the $5-\mathrm{HT}_{2 \mathrm{~A}} \mathrm{R}$ signaling occur in the $\mathrm{LHb}$, we have studied the effect of intravenous (i.v.) administration of the 5- $\mathrm{HT}_{2 \mathrm{~A}} \mathrm{R}$ agonist TCB-2 [32] on the neuronal activity of LHb neurons using extracellular single-cell recordings in vivo in acute and nicotine-treated rats. We found that acute and chronic nicotine treatments did not change the number of $\mathrm{LHb} 5-\mathrm{HT}_{2 \mathrm{~A}} \mathrm{R}$-immuno reactive (IR) neurons, while only acute nicotine increased their neuropil expression. On the other hand, TCB-2 (5-640 $\mu \mathrm{g} / \mathrm{kg}$, i.p.) in acute nicotine-treated rats induced both excitations and inhibitions of $\mathrm{LHb}$ neural activity while in chronic conditions, only inhibitions were observed.

We also studied the 5- $\mathrm{HT}_{2 \mathrm{~A}} \mathrm{R}$ expression in other areas involved in nicotine addiction such as the mPFC, hippocampal dentate gyrus (DG), the NAc, the ST, the VTA, the substantia nigra pars compacta $(\mathrm{SNc})$, and the dorsal raphe nucleus (DRN) in rats. We observed only in the DG an increase in the number of $5-\mathrm{HT}_{2 \mathrm{~A}} \mathrm{R}-\mathrm{IR}$ neurons upon acute nicotine treatment, while chronic treatment normalized their number in comparison to drug naïve values. The neuropil 5- $\mathrm{HT}_{2 \mathrm{~A}} \mathrm{R}$ expression was decreased in $\mathrm{mPFC}$ and increased in the VTA in acute nicotine-treated rats. Chronic nicotine-induced normalization in $\mathrm{mPFC}, \mathrm{DG}$, increased in NAc, and decreased in the ST. The present data indicate that acute and chronic nicotine exposure induces differential $5-\mathrm{HT}_{2 \mathrm{~A}} \mathrm{R}$ changes within the brain areas studied that 
might be responsible for the differences in the $\mathrm{LHb}$ neuronal response to TCB-2 administration in the acute and chronic conditions.

\section{Results}

\subsection{Effect of Systemic Administration of Acute and Chronic Nicotine on 5-HT $2 A$ R Immunohistochemistry} Expression in the $\mathrm{LHb}$

The $\mathrm{LHb}$ of drug naïve rats had a moderate intensity of $5-\mathrm{HT}_{2 \mathrm{~A}} \mathrm{R}$ immunostaining (Figure $1 \mathrm{~A}, \mathrm{~B}$ ). The density of $5-\mathrm{HT}_{2 \mathrm{~A}} \mathrm{R}$ immunostained somata was similar among the different experimental groups (naïve nicotine, acute and chronic nicotine) (Figure $1 \mathrm{~A}-\mathrm{F}$ ). However, the intensity of the neuropil staining was low (Figure $1 \mathrm{~A}, \mathrm{~B}$ ). The intensity of $5-\mathrm{HT}_{2 \mathrm{~A}} \mathrm{R}$-immunostaining was evident in the LHb of acute nicotine rats. Statistical analysis did not show any significant differences comparing the neuronal densities observed in the different groups.
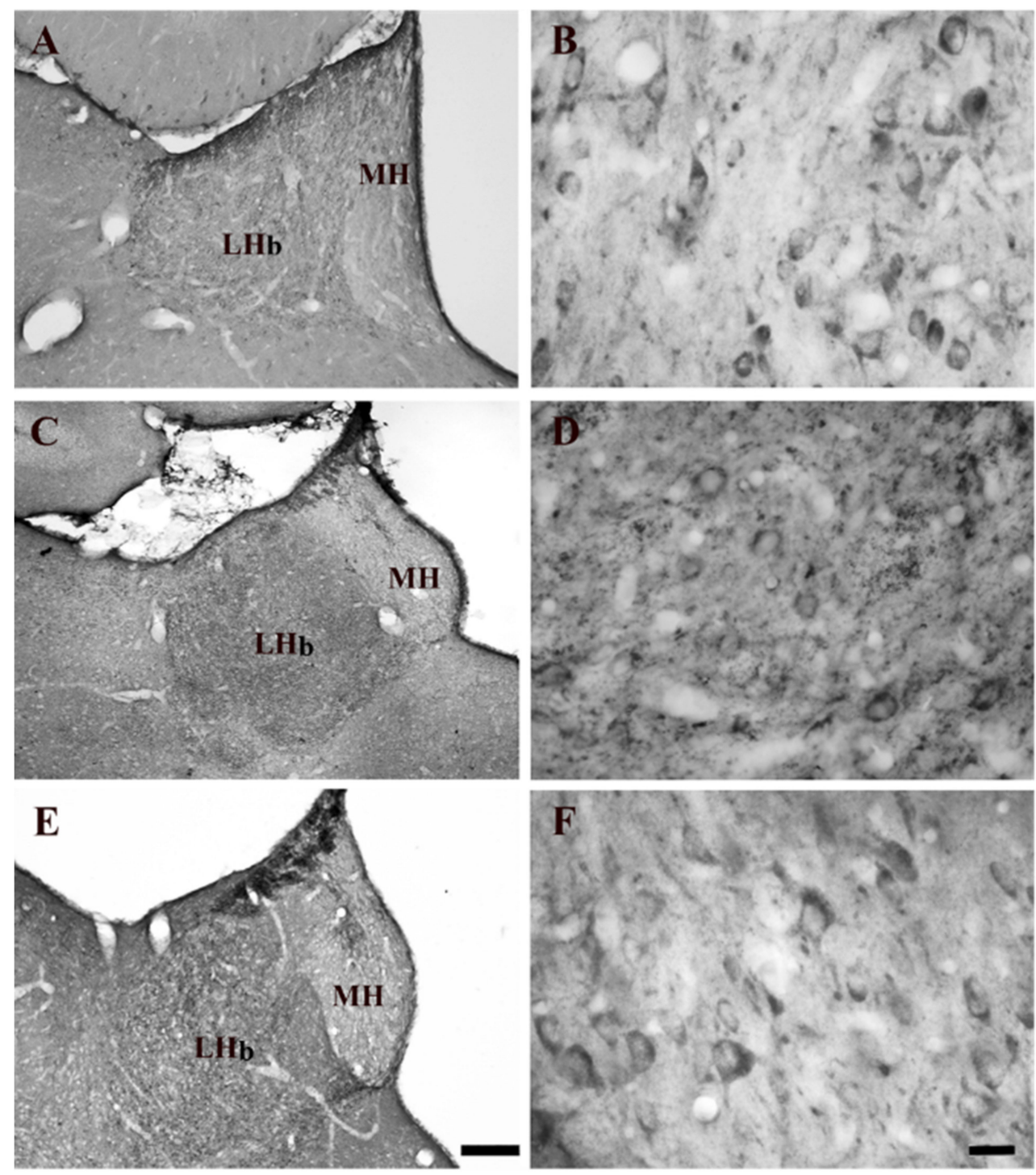

Figure 1. Brightfield photomicrographs of coronal sections showing the distribution of $5-\mathrm{HT}_{2 \mathrm{~A}}$ receptors $\left(5-\mathrm{HT}_{2 \mathrm{~A}} \mathrm{Rs}\right)$ immunoreactivity in the lateral habenula $(\mathrm{LHb})$ of nicotine-naïve $(\mathbf{A}, \mathbf{B})$, acute nicotine $(\mathbf{C}, \mathbf{D})$, and chronic nicotine (E,F). Note the high 5- $\mathrm{HT}_{2 \mathrm{~A}} \mathrm{R}$ immunoreactivity in the $\mathrm{LHb}$ of acute nicotine rats $(\mathbf{C})$. See text and Table 1 explanations. Abbreviations: $\mathrm{LHb}$, lateral habenula; $\mathrm{MH}$, medial habenula. Scale bar $=200 \mu \mathrm{m}$ in E (applies to A,C,E) and $20 \mu \mathrm{m}$ in F (applies to B,D,F). 
Table 1. 5- $\mathrm{HT}_{2 \mathrm{~A}} \mathrm{R}-\mathrm{IR}$ somata and colocalization of $\mathrm{HuC} / \mathrm{D}$ with $5-\mathrm{HT}_{2 \mathrm{~A}} \mathrm{R}$ in the rat lateral habenula.

\begin{tabular}{cccc}
\hline Lateral Habenula $(\mathbf{L H b})$ & $\begin{array}{c}\text { Naïve Nicotine } \\
(\mathbf{N N})\end{array}$ & $\begin{array}{c}\text { Acute Nicotine } \\
\text { (AN) }\end{array}$ & $\begin{array}{c}\text { Chronic Nicotine } \\
\text { (CN) }\end{array}$ \\
\hline Density 5-HT $\mathrm{HA}_{2 \mathrm{~A}} \mathrm{R}-\mathrm{IR}$ neurons & $57.1 \pm 12.3$ & $52.2 \pm 13.3$ & $51.4 \pm 13.9$ \\
$\mathrm{HuC} / \mathrm{D}-\mathrm{IR}$ neurons & 600 & 608 & 664 \\
$\mathrm{HuC} / \mathrm{D} / 5-\mathrm{HT}_{2 \mathrm{~A}} \mathrm{R}-\mathrm{IR}$ & 64 & 56 & 56 \\
$\%$ of $5-\mathrm{HT}_{2 \mathrm{~A}} \mathrm{R}-\mathrm{IR}$ & $9.6 \%(64 / 664)$ & $8.4 \%(56 / 664)$ & $7.8 \%(56 / 720)$ \\
$\%$ area covered by 5-HT $2 \mathrm{~A}$ R-IR & $53.5 \pm 8.8$ & $67.7 \pm 15.8 *$ & $58.4 \pm 11.6$ \\
\hline
\end{tabular}

The density of $5-\mathrm{HT}_{2 \mathrm{~A}}$ Rs-immunoreactive somata is expressed as the mean $/ \mathrm{mm}^{2} \pm$ standard deviation. ${ }^{*} p<0.05$, AN versus NN.

The double immunofluorescence analysis, performed in the LHb consisted of the colocalization of the $5-\mathrm{HT}_{2 \mathrm{~A}} \mathrm{R}$ with $\mathrm{HuC} / \mathrm{D}$ (pan-neuronal marker). We did not observe any significant differences in the proportion of $5-\mathrm{HT}_{2 \mathrm{~A}} \mathrm{R}-\mathrm{IR}$, comparing the different groups (Figure 2; Table 1). The percentage of the image covered by $5-\mathrm{HT}_{2 \mathrm{~A}} \mathrm{R}$ immunoreactivity showed significant differences in the LHb (Table 1 , acute nicotine $>$ nicotine-naïve) confirming immunoperoxidase experiments.

\section{LATERAL HABENULA}
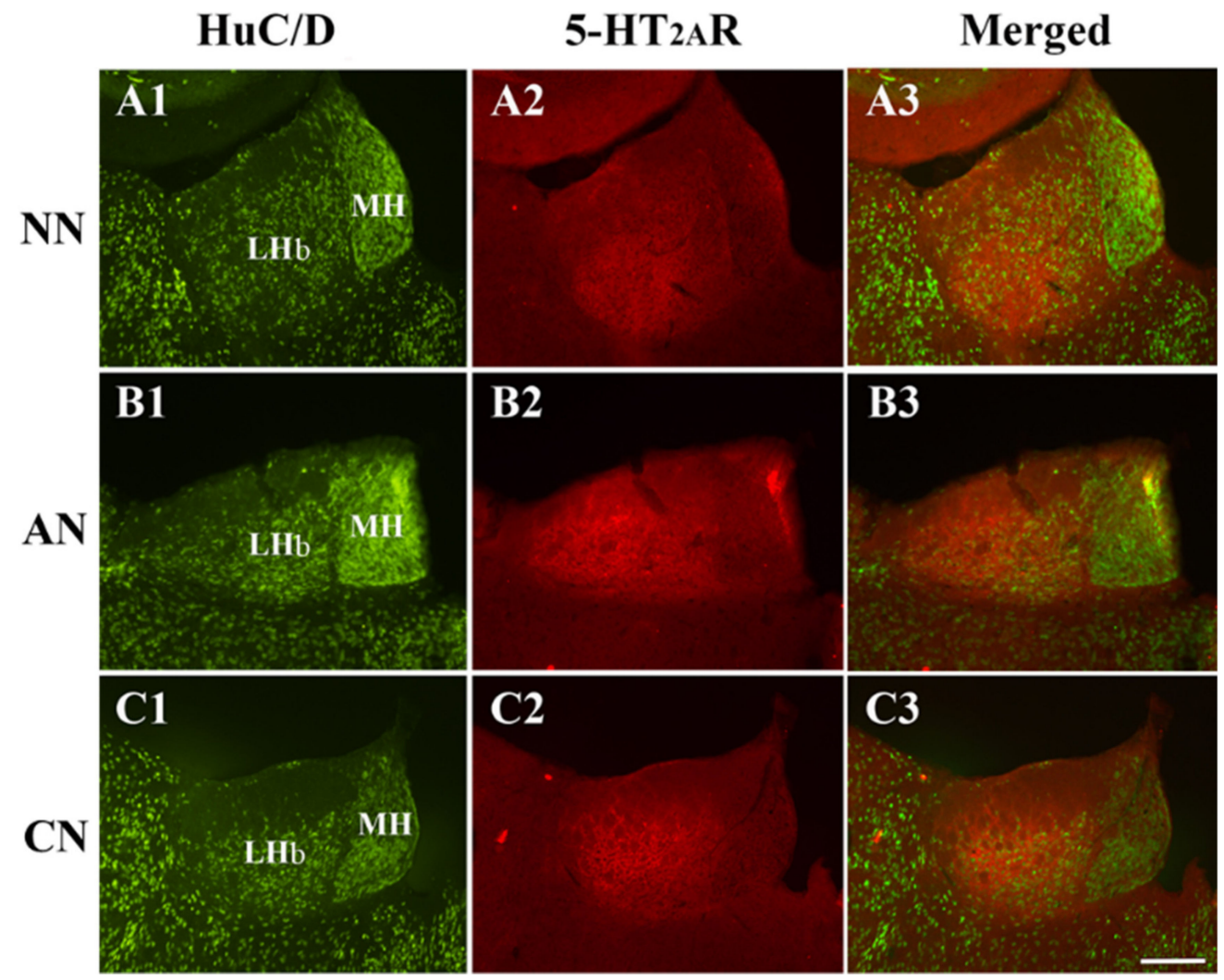

Figure 2. Colocalization of the $\mathrm{HuC} / \mathrm{D}$ (pan-neuronal marker) with $5-\mathrm{HT}_{2 \mathrm{~A}}$ receptor $\left(5-\mathrm{HT}_{2 \mathrm{~A}} \mathrm{R}\right)$ in the lateral habenula of naive nicotine (A1-A3), acute nicotine (B1-B3) and chronic nicotine (C1-C3) rats. Double immunofluorescence images showing HuC/D in green (left column pictures; A1, B1, C1), $5-\mathrm{HT}_{2 \mathrm{~A}} \mathrm{R}$ in red (middle column pictures; $\mathrm{A} 2, \mathrm{~B} 2, \mathrm{C} 2$ ), and colocalization of HuC/D with 5- $\mathrm{HT}_{2 \mathrm{~A}} \mathrm{R}$ in yellow (right column merging pictures; A3, B3, C3). Note the high 5- $\mathrm{HT}_{2 \mathrm{~A}} \mathrm{R}$ immunoreactivity in the $\mathrm{LHb}$ of acute nicotine rats. See text and Table 2 for explanations. Abbreviations: NN, naïve nicotine; $\mathrm{AN}$, acute nicotine; $\mathrm{CN}$, chronic nicotine; $\mathrm{LHb}$, lateral habenula; $\mathrm{MH}$, medial habenula. Scale bar $=200$ $\mu \mathrm{m}$ in $\mathrm{C} 3$ (applies to A1-C3). 
Table 2. Colocalization of $\mathrm{HuC} / \mathrm{D}$ with $5-\mathrm{HT}_{2 \mathrm{~A}}$ receptor $\left(5-\mathrm{HT}_{2 \mathrm{~A}} \mathrm{R}\right)$.

\begin{tabular}{|c|c|c|c|}
\hline Medial Prefrontal Cortex (mPFC) & $\begin{array}{l}\text { Naïve Nicotine } \\
\text { (NN) }\end{array}$ & $\begin{array}{l}\text { Acute Nicotine } \\
\text { (AN) }\end{array}$ & $\begin{array}{c}\text { Chronic Nicotine } \\
\text { (CN) }\end{array}$ \\
\hline HuC/D-IR neurons & 242 & 189 & 317 \\
\hline $\mathrm{HuC} / \mathrm{D} / 5-\mathrm{HT}_{2 \mathrm{~A}} \mathrm{R}-\mathrm{IR}$ & 454 & 379 & 443 \\
\hline$\%$ of $5-\mathrm{HT}_{2 \mathrm{~A}} \mathrm{R}-\mathrm{IR}$ & $65.2 \%(454 / 696)$ & $66.7 \%(379 / 568)$ & $58.3 \%(443 / 760)$ \\
\hline$\%$ area covered by $5-\mathrm{HT}_{2 \mathrm{~A}} \mathrm{R}-\mathrm{IR}$ & $75.9 \pm 14.1$ & $63.3 \pm 14.1 *$ & $76.1 \pm 13.4^{\wedge}$ \\
\hline Dentate Gyrus (DG) & NN & AN & $\mathrm{CN}$ \\
\hline HuC/D-IR neurons & 192 & 138 & 172 \\
\hline $\mathrm{HuC} / \mathrm{D} / 5-\mathrm{HT}_{2 \mathrm{~A}} \mathrm{R}-\mathrm{IR}$ & 44 & 99 & 36 \\
\hline$\%$ of $5-\mathrm{HT}_{2 \mathrm{~A}} \mathrm{R}-\mathrm{IR}$ & $18.6 \%(44 / 236)$ & $41.8 \%(99 / 237) *$ & $17.3 \%(36 / 208)$ \\
\hline$\%$ area covered by 5 -HT2AR-IR & $57.6 \pm 12.9$ & $69.6 \pm 19.7$ & $52.1 \pm 15.8^{\wedge}$ \\
\hline Nucleus Accumbens (NAc) & NN & AN & $\mathrm{CN}$ \\
\hline HuC/D-IR neurons & 33 & 31 & 36 \\
\hline $\mathrm{HuC} / \mathrm{D} / 5-\mathrm{HT}_{2 \mathrm{~A}} \mathrm{R}-\mathrm{IR}$ & 59 & 49 & 52 \\
\hline$\%$ of $5-\mathrm{HT}_{2 \mathrm{~A}} \mathrm{R}-\mathrm{IR}$ & $64.1 \%(59 / 92)$ & $61.3 \%(49 / 80)$ & $59.1 \%(52 / 88)$ \\
\hline$\%$ area covered by $5-\mathrm{HT}_{2 \mathrm{~A}} \mathrm{R}-\mathrm{IR}$ & $27.4 \pm 8.9$ & $33.6 \pm 11.9$ & $46.7 \pm 25.4 *$ \\
\hline Striatum $(\mathrm{ST})$ & NN & AN & $\mathrm{CN}$ \\
\hline HuC/D-IR neurons & 298 & 302 & 256 \\
\hline $\mathrm{HuC} / \mathrm{D} / 5-\mathrm{HT}_{2 \mathrm{~A}} \mathrm{R}-\mathrm{IR}$ & 302 & 319 & 296 \\
\hline$\%$ of $5-\mathrm{HT}_{2 \mathrm{~A}} \mathrm{R}-\mathrm{IR}$ & $50.3 \%(302 / 600)$ & $51.4 \%(319 / 621)$ & $53.6 \%(296 / 552)$ \\
\hline$\%$ area covered by $5-\mathrm{HT}_{2 \mathrm{~A}} \mathrm{R}-\mathrm{IR}$ & $71.8 \pm 13.5$ & $77.9 \pm 14.1$ & $67.1 \pm 12.4^{\wedge}$ \\
\hline Ventral Tegmental Area (VTA) & NN & AN & $\mathrm{CN}$ \\
\hline $\mathrm{HuC} / \mathrm{D}-\mathrm{IR}$ neurons & 88 & 97 & 104 \\
\hline $\mathrm{HuC} / \mathrm{D} / 5-\mathrm{HT}_{2 \mathrm{~A}} \mathrm{R}-\mathrm{IR}$ & 24 & 47 & 32 \\
\hline$\%$ of $5-\mathrm{HT}_{2 \mathrm{~A}} \mathrm{R}-\mathrm{IR}$ & $21.4 \%(24 / 112)$ & $32.6 \%(47 / 144)$ & $23.5 \%(32 / 136)$ \\
\hline$\%$ area covered by $5-\mathrm{HT}_{2 \mathrm{~A}} \mathrm{R}-\mathrm{IR}$ & $45.4 \pm 12.2$ & $59.2 \pm 14.9 *$ & $54.3 \pm 16.2$ \\
\hline Substantia Nigra Pars Compacta (SNc) & NN & AN & $\mathrm{CN}$ \\
\hline HuC/D-IR neurons & 184 & 205 & 232 \\
\hline $\mathrm{HuC} / \mathrm{D} / 5-\mathrm{HT}_{2 \mathrm{~A}} \mathrm{R}-\mathrm{IR}$ & 112 & 91 & 108 \\
\hline$\%$ of $5-\mathrm{HT}_{2 \mathrm{~A}} \mathrm{R}-\mathrm{IR}$ & $37.8 \%(112 / 296)$ & $30.7 \%(91 / 296)$ & $31.8 \%(108 / 340)$ \\
\hline$\%$ area covered by $5-\mathrm{HT}_{2 \mathrm{~A}} \mathrm{R}-\mathrm{IR}$ & $42.8 \pm 12.4$ & $49.9 \pm 13.1$ & $49.1 \pm 14.5$ \\
\hline Dorsal raphe Nucleus (DRN) & NN & AN & $\mathrm{CN}$ \\
\hline HuC/D-IR neurons & 368 & 284 & 264 \\
\hline $\mathrm{HuC} / \mathrm{D} / 5-\mathrm{HT}_{2 \mathrm{~A}} \mathrm{R}-\mathrm{IR}$ & 92 & 104 & 132 \\
\hline$\%$ of $5-\mathrm{HT}_{2 \mathrm{~A}} \mathrm{R}-\mathrm{IR}$ & $20 \%(92 / 460)$ & $26.8 \%(104 / 388)$ & $33.3 \%(132 / 396)$ \\
\hline$\%$ area covered by $5-\mathrm{HT}_{2 \mathrm{~A}} \mathrm{R}-\mathrm{IR}$ & $19.4 \pm 5.2$ & $20.1 \pm 5.9$ & $19.1 \pm 4.8$ \\
\hline
\end{tabular}

The density of $5-\mathrm{HT}_{2 \mathrm{~A}}$ receptors-immunoreactive somata is expressed as the mean $/ \mathrm{mm}^{2} \pm$ standard deviation. ${ }^{*} p<$ 0.05 , acute nicotine (AN) versus naïve nicotine (NN). ${ }^{\wedge} p<0.05$, chronic nicotine (AN) versus acute nicotine (NN).

\subsection{5-HT $2 A$ R Electrophysiology Experiments}

\subsubsection{Electrophysiological Characteristics of Spontaneously Active the LHb Neurons}

We recorded 70 spontaneously active neurons extracellularly in the LHb. The neurons fired at $11.9 \pm 0.67 \mathrm{~Hz}$ with a waveform duration of $1.1 \pm 0.01 \mathrm{~ms}$. The LHb neurons recorded had a predominantly $(82.9 \%)$ biphasic waveform and three distinct firing patterns; the majority were irregular $(82.9 \%)$, while regular and bursty neurons contributed to less than $10 \%$. The average coefficient of variation $(\mathrm{CV})$ was $0.74 \pm 0.03$, and as expected was greatest in burst firing neurons and lowest in regular firing neurons (data not shown).

2.2.2. Effect of Systemic Administration of 5- $\mathrm{HT}_{2 \mathrm{~A}} \mathrm{R}$ Agonist TCB-2 on the Firing Rate and Pattern of $\mathrm{LHb}$ Neurons of Acute and Chronic-Treated Rats

ANOVA analysis shows that the administration of TCB-2 (5-640 $\mu \mathrm{g} / \mathrm{kg}$, iv) after $60 \mathrm{~min}$ from the acute nicotine-treatment $(2 \mathrm{mg} / \mathrm{kg}$; i.p.) induced a significant increase and decrease of the $\mathrm{LHb}$ neuronal firing rate (Figure $3 \mathrm{~A}, \mathrm{~B})$. 
A

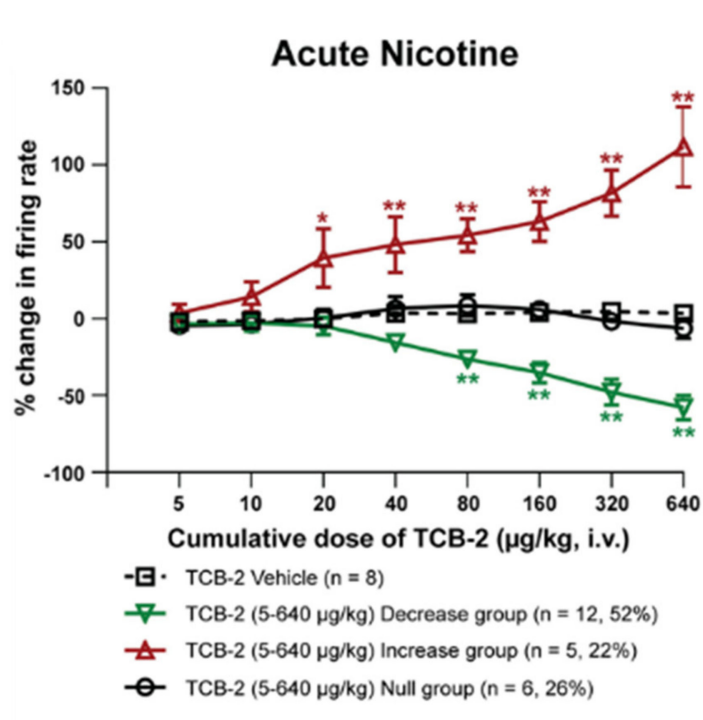

C

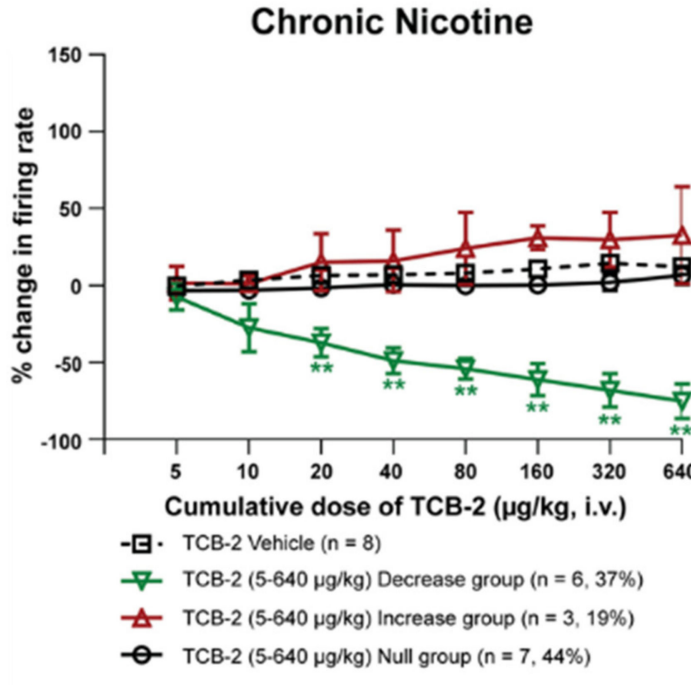

B
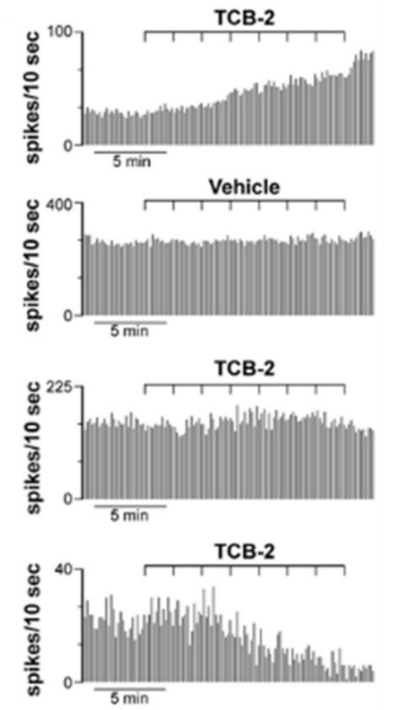

D
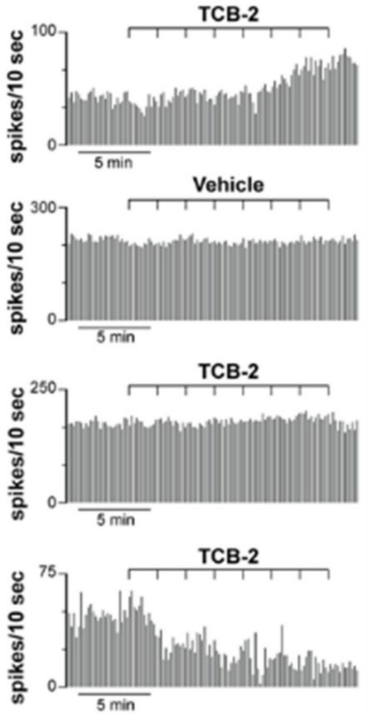

Figure 3. (A). The dose-response curve of TCB-2 (5-640 $\mu \mathrm{g} / \mathrm{kg}$, iv) $60 \mathrm{~min}$ after a single acute treatment of nicotine $(2 \mathrm{mg} / \mathrm{kg}$, i.p.). The data are shown as the mean $\%$ change in firing rate $\pm \mathrm{SEM}$. The majority of neurons (52\%) responded with a decrease in firing rate, with peak effect at $640 \mu \mathrm{g} / \mathrm{kg}(-57.8 \pm 7.9 \%)$. The remaining neurons responded with an increase in firing rate $(22 \%$, peak effect at $640 \mu \mathrm{g} / \mathrm{kg}$, $111.7 \pm 26.1 \%)$, or showed no change in firing rate (26\%). One-way ANOVA with repeated-measures, followed by Tukey's post hoc test, ${ }^{*} p<0.05$ vs Vehicle, ${ }^{* *} p<0.005$ vs Vehicle. (B) Typical rate histograms of single neuronal recordings that showed an increase in firing, a control neuron, no change in firing, and a decrease in firing (sequentially from top to bottom). (C) A dose-response curve of TCB-2 (5-640 $\mu \mathrm{g} / \mathrm{kg}$, i.v.) after chronic treatment of nicotine ( $6 \mathrm{mg} / \mathrm{kg} /$ day for 14 days). Almost an equal number of neurons responded with no change in firing rate $(44 \%)$ or with a decrease in firing rate $(37 \%$, peak effect at $640 \mu \mathrm{g} / \mathrm{kg},-75.0 \pm 11.4 \%$ ). The remaining neurons responded with a small, not significant increase in firing rate $(19 \%$, peak effect at $640 \mu \mathrm{g} / \mathrm{kg}, 32.7 \pm 31.4 \%)$. (D). Typical rate histograms of single neuronal recordings that showed an increase in firing, a control neuron, no change in firing, and a decrease in firing (sequentially from top to bottom). One-way ANOVA with repeated-measures, followed by Tukey's post hoc test, ${ }^{*} p<0.05$ vs Vehicle, ${ }^{* *} p<0.005$ vs. Vehicle.

After chronic treatment of nicotine $(6 \mathrm{mg} / \mathrm{kg} / \mathrm{day}$ for 14 days), TCB-2 (5-640 $\mu \mathrm{g} / \mathrm{kg}$, i.v.) induced almost in an equal number of neurons either no change in firing rate $(n=7 ; 44 \%)$ or a decrease in firing rate $(n=6 ; 37 \%)$ with a peak effect at $640 \mu \mathrm{g} / \mathrm{kg}$ of $-75.0 \pm 11.4 \%(p<0.005 ;$ post-hoc Tukey test $)$ when 
compared to the control group. The remaining neurons responded with no significant increase in firing rate $(n=3 ; 19 \%$, peak effect at $640 \mu \mathrm{g} / \mathrm{kg}, 32.7 \pm 31.4 \%, p=0.585$ post-hoc Tukey test Figure 3C,D). The chronic inhibitory group was not different from the acute inhibitory one at any of the doses tested (two-way ANOVA followed by Tukey's test, $p=0.9$ ).

\subsection{5-HT ${ }_{2 A}$ R Colocalization Studies in the mPFC, DG, NAc, ST, VTA, SNc, and DRN}

The double immunofluorescence analysis, performed on mPFC, DG, ST, NAc, VTA, SNc, and DRN consisted of the colocalization of the $5-\mathrm{HT}_{2 \mathrm{~A}} \mathrm{R}$ with $\mathrm{HuC} / \mathrm{D}$ (pan-neuronal marker) (Figures 4-6 and Figures S1-S8). Except for the DG (polymorphic layer Figure 4), we did not observe any significant differences in the proportion of $5-\mathrm{HT}_{2 \mathrm{~A}} \mathrm{R}-\mathrm{IR}$, comparing the different groups (Figures 3-6 and Figures S1-S8; Table 2). The proportion of 5- $\mathrm{HT}_{2 \mathrm{~A}} \mathrm{R}-\mathrm{IR}$ neurons in the polymorphic layer of the DG was significantly higher in acute nicotine rats than in nicotine-naïve and chronic nicotine rats (Figure 4; Table 2). In the polymorphic layers, the percentage of the image covered by $5-\mathrm{HT}_{2 \mathrm{~A}} \mathrm{R}$ immunoreactivity was significantly higher in acute nicotine rats than in chronic nicotine rats. In fact, in acute nicotine, there was an increase in the proportion of double-labeled cells (only for acute nicotine rats) and the neuropilar immunostaining (Figure 4; Table 2). The percentage of the image covered by $5-\mathrm{HT}_{2 \mathrm{~A}} \mathrm{R}$ immunoreactivity showed significant differences also in the MPFC (nicotine-naïve and chronic nicotine $>$ acute nicotine), ST (acute nicotine $>$ chronic nicotine), NAc (chronic nicotine $>$ nicotine-naïve), and VTA (acute nicotine $>$ nicotine-naïve) (Table 2). These differences were related to different neuropilar immunostaining. Accordingly, the proportion of $5-\mathrm{HT}_{2 \mathrm{~A}} \mathrm{R}-\mathrm{IR}$ neurons did not show any significant difference in $\mathrm{mPFC}, \mathrm{ST}, \mathrm{NAc}$, and VTA comparing the different groups (Table 2).

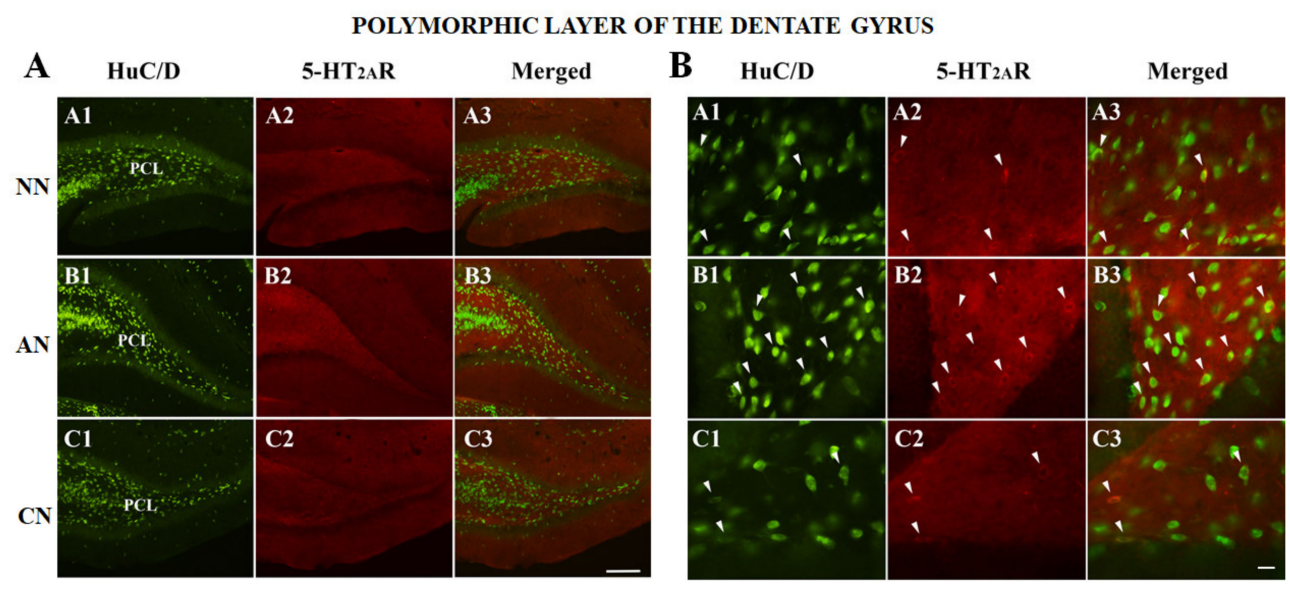

Figure 4. (A) Colocalization of the $\mathrm{HuC} / \mathrm{D}$ with $5-\mathrm{HT}_{2 \mathrm{~A}}$ receptor $\left(5-\mathrm{HT}_{2 \mathrm{~A}} \mathrm{R}\right)$ in the dentate gyrus (polymorphic cell layer) of naïve nicotine (NN) (A1-A3), acute nicotine (AN) (B1-B3) and chronic nicotine $(\mathrm{CN})(\mathrm{C} 1-\mathrm{C} 3)$ rats. Double immunofluorescence images showing HuC/D in green (left column pictures; $\mathrm{A} 1, \mathrm{~B} 1$ and $\mathrm{C} 1$ ), $5-\mathrm{HT}_{2 \mathrm{~A}} \mathrm{R}$ in red (middle column pictures; $\mathrm{A} 2, \mathrm{~B} 2$ and $\mathrm{C} 2$ ), and colocalization of $\mathrm{HuC} / \mathrm{D}$ with $5-\mathrm{HT}_{2 \mathrm{~A}} \mathrm{R}$ in yellow (right column merging pictures; $\mathrm{A} 3, \mathrm{~B} 3$ and $\mathrm{C} 3$ ). Note the high $5-\mathrm{HT}_{2 \mathrm{~A}} \mathrm{R}$ immunoreactivity in the polymorphic cell layer of acute nicotine rats. See text and Table 2 for explanations. Abbreviations: PCL, polymorphic cell layer. Scale bar $=200 \mu \mathrm{m}$ in C3 (applies to A1-C3). (B) Colocalization of the HuC/D with 5-HT $\mathrm{HA}_{\mathrm{A}} \mathrm{R}$ in the dentate gyrus (polymorphic cell layer) of nicotine-naïve (A1-A3), acute nicotine (B1-B3), and chronic nicotine (C1-C3) rats. Double immunofluorescence images showing $\mathrm{HuC} / \mathrm{D}$ in green (left column pictures; $\mathrm{A} 1, \mathrm{~B} 1$, and $\mathrm{C} 1$ ), $5-\mathrm{HT}_{2 \mathrm{~A}} \mathrm{R}$ in red middle column pictures; $\mathrm{A} 2, \mathrm{~B} 2$, and C2), and colocalization of $\mathrm{HuC} / \mathrm{D}$ with $5-\mathrm{HT}_{2 \mathrm{~A}} \mathrm{R}$ in yellow (right column merging pictures; A3, B3, and C3 arrowheads indicate double-labeled neurons). Note that in acute nicotine rats there are more $\mathrm{d}$ (ouble-labeled neurons than in nicotine-naïve and chronic nicotine rats. See text and Table 2 for explanations. Scale bar $=25 \mu \mathrm{m}$ in C3 (applies to A1-C3). 


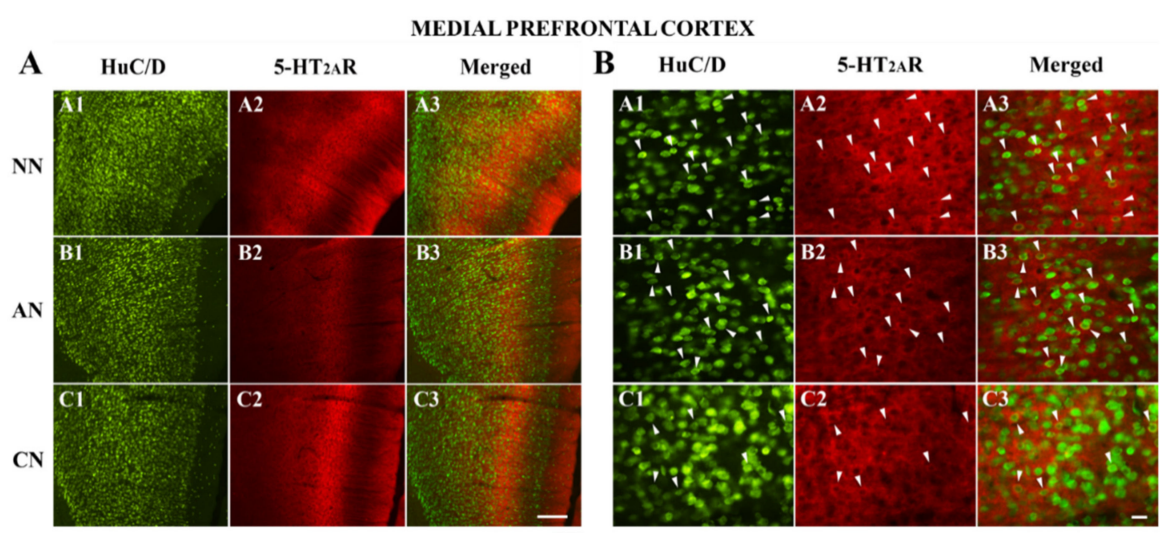

Figure 5. (A) Colocalization of the $\mathrm{HuC} / \mathrm{D}$ with $5-\mathrm{HT}_{2 \mathrm{~A}}$ receptor $\left(5-\mathrm{HT}_{2 \mathrm{~A}} \mathrm{R}\right)$ in the medial prefrontal cortex (mPFC, layers V and VI) of naïve nicotine (NN) (A1-A3), acute nicotine (AN) (B1-B3) and chronic nicotine $(\mathrm{CN})(\mathrm{C} 1-\mathrm{C} 3)$ rats. Double immunofluorescence images showing HuC/D in green (left column pictures; $\mathrm{A} 1, \mathrm{~B} 1$, and $\mathrm{C} 1$ ), $5-\mathrm{HT}_{2 \mathrm{~A}} \mathrm{R}$ in red (middle column pictures; $\mathrm{A} 2, \mathrm{~B} 2$, and $\mathrm{C} 2$ ), and colocalization of $\mathrm{HuC} / \mathrm{D}$ with $5-\mathrm{HT}_{2 \mathrm{~A}} \mathrm{R}$ in yellow (right column merging pictures; $\mathrm{A} 3, \mathrm{~B} 3$, and $\mathrm{C} 3$ ). Note the high 5- $\mathrm{HT}_{2 \mathrm{~A}} \mathrm{R}$ immunoreactivity in the $\mathrm{mPFC}$ of nicotine-naïve and chronic nicotine rats. See text and Table 2 for explanations. Scale bar $=200 \mu \mathrm{m}$ in C3 (applies to A1-C3). (B) Colocalization of the $\mathrm{HuC} / \mathrm{D}$ with $5-\mathrm{HT}_{2 \mathrm{~A}}$ receptor $\left(5-\mathrm{HT}_{2 \mathrm{~A}} \mathrm{R}\right)$ in the $\mathrm{mPFC}$ (layers $\mathrm{V}$ and $\mathrm{VI}$ ) of nicotine-naïve (A1-A3), acute nicotine (B1-B3), and chronic nicotine (C1-C3) rats. Double immunofluorescence images showing $\mathrm{HuC} / \mathrm{D}$ in green (left column pictures; $\mathrm{A} 1, \mathrm{~B} 1$, and $\mathrm{C} 1$ ), $5-\mathrm{HT}_{2 \mathrm{~A}} \mathrm{R}$ in red (middle column pictures; $\mathrm{A} 2$, $\mathrm{B} 2$, and $\mathrm{C} 2$ ), and colocalization of $\mathrm{HuC} / \mathrm{D}$ with $5-\mathrm{HT}_{2 \mathrm{~A}} \mathrm{R}$ in yellow (right column merging pictures; $\mathrm{A} 3$, $\mathrm{B} 3$, and $\mathrm{C} 3$ arrowheads indicate double-labeled neurons). The proportion of $5-\mathrm{HT}_{2 \mathrm{~A}} \mathrm{R}$-immunoreactive neurons to the total neurons does not show significant differences comparing the different groups. See text and Table 2 for explanations. Scale bar $=25 \mu \mathrm{m}$ in C3 (applies to A1-C3).

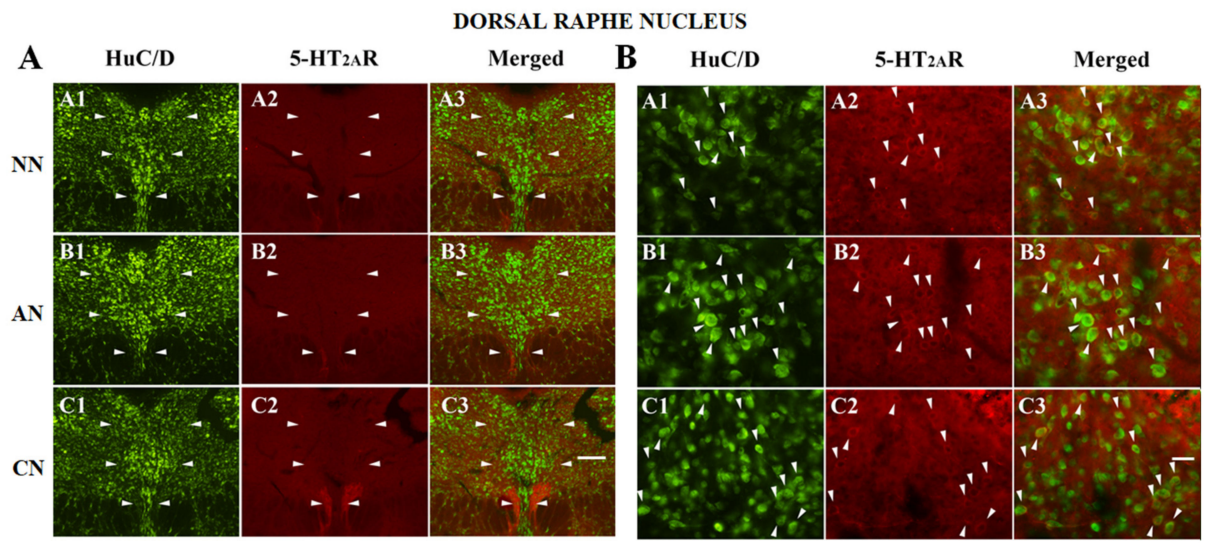

Figure 6. (A) Colocalization of the $\mathrm{HuC} / \mathrm{D}$ with $5-\mathrm{HT}_{2 \mathrm{~A}}$ receptor $\left(5-\mathrm{HT}_{2 \mathrm{~A}} \mathrm{R}\right)$ in the dorsal raphe nucleus (DRN, bordered by arrowheads) of naïve nicotine (NN) (A1-A3), acute nicotine (AN) (B1-B3), and chronic nicotine $(\mathrm{CN})(\mathrm{C} 1-\mathrm{C} 3)$ rats. Double immunofluorescence images showing HuC/D in green (left column pictures; $\mathrm{A} 1, \mathrm{~B} 1$, and $\mathrm{C} 1$ ), $5-\mathrm{HT}_{2 \mathrm{~A}} \mathrm{R}$ in red (middle column pictures; $\mathrm{A} 2, \mathrm{~B} 2$, and $\mathrm{C} 2$ ), and colocalization of $\mathrm{HuC} / \mathrm{D}$ with $5-\mathrm{HT}_{2 \mathrm{~A}} \mathrm{R}$ in yellow (right column merging pictures; $\mathrm{A} 3, \mathrm{~B} 3$, and C3). The immunoreactivity for the $5-\mathrm{HT}_{2 \mathrm{~A}} \mathrm{R}$ is similar in the different groups. See text and Table 2 for explanations. Scale bar $=200 \mu \mathrm{m}$ in C3 (applies to A1-C3). (B) Colocalization of the HuC/D with $5-\mathrm{HT}_{2 \mathrm{~A}} \mathrm{R}$ in the DRN of naive nicotine (A1-A3), acute nicotine (B1-B3), and chronic nicotine (C1-C3) rats. Double immunofluorescence images showing HuC/D in green (left column pictures; A1, B1, and $\mathrm{C} 1$ ), $5-\mathrm{HT}_{2 \mathrm{~A}} \mathrm{R}$ in red (middle column pictures; $\mathrm{A} 2$, B2, and $\mathrm{C} 2$ ), and colocalization of HuC/D with $5-\mathrm{HT}_{2 \mathrm{~A}} \mathrm{R}$ in yellow (right column merging pictures; A3, B3, and C3 arrowheads indicate double-labeled neurons). The proportion of $5-\mathrm{HT}_{2 \mathrm{~A}} \mathrm{R}$-immunoreactive neurons to the total neurons does not show significant differences comparing the different groups. See text and Table 2 for explanations. Scale bar $=25 \mu \mathrm{m}$ in C3 (applies to A1-C3). 


\section{Discussion}

Here we reported for the first time that acute and chronic nicotine treatment affected the $5-\mathrm{HT}_{2 \mathrm{~A}} \mathrm{R}$ expression and electrophysiological functionality in the LHb. Indeed, acute nicotine $(2 \mathrm{mg} / \mathrm{kg}$, i.p.) increased the $\mathrm{LHb} 5-\mathrm{HT}_{2 \mathrm{~A}} \mathrm{R}$ neuropil expression while chronic nicotine treatment $(6 \mathrm{mg} / \mathrm{kg} / \mathrm{day}$ for 14 days, i.p.) decreased the neuropil IR to the nicotine-naïve levels. Of note, both acute and chronic nicotine treatments did not modify the number of $\mathrm{LHb}$ neurons expressing $5-\mathrm{HT}_{2 \mathrm{~A}} \mathrm{Rs}$. Interestingly, chronic nicotine treatment changed the effect of peripheral administration of $5-\mathrm{HT}_{2 \mathrm{~A}} \mathrm{R}$ agonist TCB-2 [32-34], which was capable of producing only inhibitions of the $\mathrm{LHb}$ neurons, while both excitation and inhibition of the $\mathrm{LHb}$ neuronal activity were observed after acute nicotine treatment.

A complicated pattern of effects by acute and nicotine exposure on these receptors in the areas known to be involved in the nicotine effects in the CNS was revealed. The increase of $5-H_{2 A} R-I R$ neurons occurred only in the hippocampal DG in nicotine acute-treated rats. The most common effect of nicotine exposure was a change of the neuropil $5-\mathrm{HT}_{2 \mathrm{~A}} \mathrm{R}$ expression, either as a decrease in $\mathrm{mPFC}$ (acute nicotine) and the ST (chronic nicotine) or as an increase in the VTA (acute nicotine) and the NAc (chronic nicotine). Chronic nicotine treatment induced normalization of neuropil 5- $\mathrm{HT}_{2 \mathrm{~A}} \mathrm{R}-\mathrm{IR}$ in the mPFC and the DG.

Our data on the $\mathrm{LHb}$ further support the significant involvement of this small epithalamic area $[28,29]$ and the $5-\mathrm{HT}_{2 \mathrm{~A}} \mathrm{R}$ system $[17,35]$ and their interaction in nicotine effects in the brain and, in general, in drug dependency. Nicotine's modulation is a complex phenomenon and, apart from the rewarding effect mediated by increasing DAergic transmission [7], this alkaloid modulates different neurotransmitter systems. Among them, nicotine affects 5-HT neurons and 5-HT-innervated brain areas $[17,36]$. For instance, the $\mathrm{LHb}$ receives a dense serotonergic innervation from the raphe nuclei [30], expresses several 5-HTR subtypes [30,31], the $H T 2 A$ gene [37], and 5- $\mathrm{HT}_{2 \mathrm{~A}} \mathrm{R}$ protein, both on neurons and glial cells [34]. Here, in line with our previous study, we found that only a small population of $\mathrm{LHb}$ neurons $(9-8 \%)$ was $5-\mathrm{HT}_{2 \mathrm{~A}} \mathrm{R}-\mathrm{IR}$, independently from the nicotine treatment. Interestingly, we detected an increase of the area covered by $5-\mathrm{HT}_{2 \mathrm{~A}} \mathrm{R}-\mathrm{IR}$ in acute nicotine-treated animals that was decreased by 14 days of nicotine treatment to drug-naïve animal levels. It is difficult to identify from our immunohistochemistry (IHC) evidence the precise location of these overexpressed receptors after acute nicotine treatment, considering that they might be due to an upregulation on either presynaptic GABA/GLU input, glial cells or $\mathrm{LHb}$ cell dendrites.

Despite the increase in 5- $\mathrm{HT}_{2 \mathrm{~A}} \mathrm{R}-\mathrm{IR}$, we did not observe any change in the electrophysiological responses of the LHb neurons induced by systemic administration of TCB- 2 in acute nicotine-treated animals compared to those reported in drug naïve animals, with the majority (52\%) of the LHb neurons being decreased of about $60 \%$ of their firing rate, and the $22 \%$ of the neurons being excited $(\sim+110 \%)$ by TCB-2. Surprisingly, TCB-2 administration in chronic nicotine-treated animals did not cause any significant excitation, as seen in acute-treated (present results) and drug-naïve animals [34], while it was still capable of inducing a similar neuronal inhibition. This might suggest that the changes in $5-\mathrm{HT}_{2 \mathrm{~A}} \mathrm{R}$ expression observed in the $\mathrm{LHb}$ at the level of the local neural processes or in other areas innervating the $\mathrm{LHb}$ were functionally balanced in acute, but not in chronic nicotine treated animals. A supersensitivity of 5- $\mathrm{HT}_{1 \mathrm{~A}} \mathrm{R}$ response to $5-\mathrm{HT}_{1 \mathrm{~A}} \mathrm{R}$ agonist 8-OH-DPAT treatment was observed after nicotine withdrawal with the same nicotine dose of $6 \mathrm{mg} / \mathrm{kg} /$ day used in the current study in the DRN, but not after chronic treatment [38]. A later c-Fos study partially confirmed these findings that chronic treatment and nicotine withdrawal led to a robust $5-\mathrm{HT}_{1 \mathrm{~A}} \mathrm{R}$-mediated inhibition in the caudal pole of the DRN [39]. Our electrophysiological evidence instead shows, for the first time, the possibility of a change in electrophysiological response pattern to a 5-HTR stimulation after nicotine treatment in the $\mathrm{LHb}$ with the occlusion of the excitatory response after chronic nicotine treatment. Further experiments will be necessary to clarify the biological mechanism of such a shift in the 5-HT modulation of the LHb neuronal activity under chronic nicotine exposure.

Nicotine increases LHb neuron activity when acutely administered in vivo [26], depolarizing directly LHb neurons via postsynaptic $\alpha 6$-containing $\left(\alpha 6^{*}\right)$ nAChRs but also modulating GABA and 
GLU input onto LHb neurons [40]. The involvement of 5-HT inputs on the nicotine effect in the LHb is also probable. Moreover, $5-\mathrm{HT}_{2 \mathrm{~A} / 2 \mathrm{C}} \mathrm{Rs}$ are functionally expressed in the $\mathrm{LHb}[34]$ and mediate presynaptic 5-HT-induced potentiation of GLU transmission [41], and postsynaptic LHb neuronal excitation [42] in vitro, and mixed-effects in vivo [34]. Further, $5-\mathrm{HT}_{2 \mathrm{~A}} \mathrm{R} /$ nicotine interaction in the $\mathrm{LHb}$ can be also indirect since nicotine induces the release of $5-\mathrm{HT}$ in different brain areas $[36,43]$ that project to $\mathrm{LHb}$ such as DRN $[30,31]$.

Our IHC findings show that $5-\mathrm{HT}_{2 \mathrm{~A}}$ Rs are expressed in areas related to the nicotine effect, with a cellular and subcellular distribution in drug-naïve rats in line with previous evidence $[23,44]$. We are the first to report bidirectional changes in $5-\mathrm{HT}_{2 \mathrm{~A}} \mathrm{R}$ expression after acute nicotine treatment in the $\mathrm{LHb}$ (increase), mPFC (decrease), DG, and VTA (increase) neuropil, and no change in the number of the neurons in the LHb, mPFC, NAc, ST, VTA, SNc, DRN. In line with our results, acute nicotine $(0.4 \mathrm{mg} / \mathrm{kg})$ after five days of repeated vehicle administration increased $\left[{ }^{3} \mathrm{H}\right]$ ketanserin binding to $5-\mathrm{HT}_{2 \mathrm{~A}} \mathrm{Rs}$ in the VTA. Only in the hippocampal DG, we observed a robust increase (more than doubled) of the $5-\mathrm{HT}_{2 \mathrm{~A}} \mathrm{R}-\mathrm{IR}$ neurons. As far as the chronic nicotine effect on $5-\mathrm{HT}_{2 \mathrm{~A}} \mathrm{R}$ expression is concerned, we found an increase only in the neuropil expression of the NAc while repeated treatment with nicotine evoked significant increases in $\left[{ }^{3} \mathrm{H}\right]$ ketanserin binding to $5-\mathrm{HT}_{2 \mathrm{~A}} \mathrm{R}$ receptors in the $\mathrm{mPFC}, \mathrm{ST}$, and VTA [24]. The difference in the length of the chronic treatment ( 5 days vs. our 21 days) and dose (0.4 $\mathrm{mg} / \mathrm{kg}$ day versus our $6 \mathrm{mg} / \mathrm{kg} /$ day) used might explain the different results.

Moreover, the authors did not protect the possible binding of ketanserin on the "tetrabenazine" site (monoamine vesicular transporter), which could contribute to the effects, particularly in brain regions densely innervated with monoaminergic neurons $[45,46]$. On the other hand, IHC is more of a qualitative approach at variance with quantitative autoradiographic studies. Based on the present data, it is challenging to sort out the precise profile of the plastic changes associated with the effect of nicotine in the CNS. The changes could be quantitative and qualitative in a few brain regions, thereby leading to an imbalance of 5- $\mathrm{HT}_{2 \mathrm{~A}} \mathrm{R}$ transmission within the networks associated with nicotine effects.

We previously showed that acute nicotine induces an increase of the LHb neuronal activity in vivo [42] that might be related to its noxious/aversive effect [29,47] and reduced rewarding effect by inhibiting VTA dopaminergic neurons via the rostromedial tegmental neurons [48]. Here we found that $5-\mathrm{HT}_{2 \mathrm{~A}} \mathrm{Rs}$ are overexpressed in the $\mathrm{LHb}$ after exposure to acute nicotine and TCB-2 administration induces mainly inhibitory effects on LHb neurons of acute-treated animals. Therefore, TCB-2 might be able to counteract the nicotine-induced excitation of $\mathrm{LHb}$ activity. This effect mediated by $5-\mathrm{HT}_{2 \mathrm{~A}} \mathrm{R}$ would reduce that initial aversion due to the first cigarette and may promote nicotine addiction [49]. In line with our findings, it has been shown that $5-\mathrm{HT}_{2 \mathrm{~A}} \mathrm{R}$ activation opposes some of the behavioral effects of nicotine. For instance, 2,5-dimethoxy-4-iodoamphetamine (( \pm -DOI), a 5- $\mathrm{HT}_{2 \mathrm{~A} / 2 \mathrm{C}} \mathrm{R}$ agonist, blocked the development of the sensitization to the locomotor effects and its associated dopamine release in the NAc of repeated nicotine in rats but did not alter the acute stimulant effect of nicotine [50]. Moreover, DOI prevented the initial suppression of locomotion induced by nicotine [51] and attenuates the discriminative stimulus properties of nicotine [51,52].

On the other hand, it has been shown that $5-\mathrm{HT}_{2 \mathrm{~A}}$ Rs mediate some of the nicotine effects. Indeed, nicotine cognitive and reinforcing effects were blocked by ketanserin [53,54], and M100907, a selective $5-\mathrm{HT}_{2 \mathrm{~A}} \mathrm{R}$ antagonist prevented reinstatement of nicotine self-administration by nicotine prime or drug-associated cue [20] and nicotine sensitization [55]. Here, we showed that acute nicotine enhanced 5 - $\mathrm{HT}_{2 \mathrm{~A}} \mathrm{R}$-IR neurons of the DG, this might contribute to nicotine-enhanced hippocampal-dependent learning [56] considering $5-\mathrm{HT}_{2 \mathrm{~A}} \mathrm{R}$ participates significantly to the well-documented contribution of 5-HT to memory [57,58]. TCB-2, indeed, can improve cognitive dysfunction [59] and enhance hippocampal and amygdala-dependent memory [60]. The increased expression of 5- $\mathrm{HT}_{2 \mathrm{~A}} \mathrm{Rs}$ in the neuropil of mPFC and VTA might contribute to nicotine-induced enhanced cognition [61] and positive reinforcement [18]. Our data show that during chronic nicotine exposure, TCB-2 by sharply reducing the neuronal activity of the $\mathrm{LHb}$ neurons might contextually decrease nicotine aversion facilitating and sustaining nicotine addiction. Moreover, the $5-\mathrm{HT}_{2 \mathrm{~A}} \mathrm{R}$ activity also seems to be involved in mediating 
physical nicotine dependence, and M100907 and pimavanserin reduced the symptoms of nicotine withdrawal syndrome [62]. In addition, nicotine withdrawal increased $\left[{ }^{3} \mathrm{H}\right]$ ketanserin binding to $5-\mathrm{HT}_{2 \mathrm{~A}} \mathrm{R}$ receptors in the VTA and ventral DG, yet decreased binding in the NAc shell [63].

The major limitation of our study is that nicotine was peripherally administered. Therefore, the changes observed here on the $5-\mathrm{HT}_{2 \mathrm{~A}} \mathrm{R}$ system after acute and chronic nicotine exposure might be different from that induced in animals allowed to voluntary nicotine intake. Moreover, we have used a high dose of nicotine that might correlate with only high blood concentration of heavy smokers. This might be biased since it is known that the nicotine effect on the $\mathrm{LHb}$, for example, changes according to the dose [42].

In conclusion, our data are important in the context of the mechanisms involving the $5-\mathrm{HT}_{2 \mathrm{~A}} \mathrm{Rs}$, the $\mathrm{LHb}$ and other brain areas in nicotine addiction. Nevertheless, additional data are warranted to further our understanding of the myriad influences of $5-\mathrm{HT}_{2 \mathrm{~A}} \mathrm{Rs}$ and untangle the brain circuitry behind the effects of TCB-2 in the LHb during nicotine exposure. Along with other laboratories, we suggest that $5-\mathrm{HT}_{2 \mathrm{~A}} \mathrm{R}$ agonists sustain nicotine addictive properties, while antagonists may have a role in the development of new treatment for nicotine dependence in humans.

\section{Materials and Methods}

\subsection{Animals}

Male Sprague-Dawley rats, obtained from Charles River Laboratories in Margate, UK, and maintained at the Department of Physiology and Biochemistry at the University of Malta, were housed at $21 \pm 1{ }^{\circ} \mathrm{C}$, with $60 \pm 5 \%$ humidity, and a $12 \mathrm{~h} \mathrm{light/dark} \mathrm{cycle} \mathrm{(lights} \mathrm{on} \mathrm{at} 7$ a.m. and off at 7 p.m.). Food and water were provided ad libitum. Adult rats that weighed 270-320 g on the day of surgery or brain extraction were used. All the animals' procedures were in accordance with the European Union (EU) Directive 2010/63/EU and the Institutional Animal Use and Care Committee (IAUCC) of the University of Malta (1556, 10 April 2017). Utmost care was taken to limit the number of rats used and their suffering.

\subsection{Histological Procedures and Immunocytochemistry}

Animals and Fixation

Twenty-four rats (eight naïve nicotine, eight acute nicotine and eight chronic nicotine) were used. The animals were deeply anesthetized with a mixture $(4.0 \mathrm{~mL} / \mathrm{kg})$ of sodium pentobarbital $(48 \mathrm{mg} / \mathrm{kg})$ and chloral hydrate $(40 \mathrm{mg} / \mathrm{kg}$; intraperitoneally) and perfused intracardially using a peristaltic pump (flow rate $30-35 \mathrm{~mL} / \mathrm{min}$ ) as follows: $0.9 \%$ saline $\left(+4{ }^{\circ} \mathrm{C}\right.$ ) for $2 \mathrm{~min}$, followed by a solution of $4 \%$ paraformaldehyde in $0.1 \mathrm{M}$ sodium phosphate buffer, $\mathrm{pH} 7.4$ (flow rate $10 \mathrm{~mL} / \mathrm{min}$ ) for $30 \mathrm{~min}$. The brains were removed from the skull and postfixed in the final fixative for 2 to $4 \mathrm{~h}$. The brains were then cryoprotected in $30 \%$ sucrose solution in phosphate-buffered saline (PBS), pH 7.4 at $+4{ }^{\circ} \mathrm{C}$ for $48 \mathrm{~h}$, and cut in the coronal plane at $30 \mu \mathrm{m}$ section thickness on a freezing sliding microtome. The sections ( 1 in 5 series) were stored in $30 \%$ sucrose solution in PBS at $-20^{\circ} \mathrm{C}$ (for immunohistochemical staining) or in $10 \%$ formalin at room temperature (for thionin staining) until processed.

\subsection{Immunoperoxidase Experiments}

Immunoperoxidase staining was performed on the $\mathrm{LHb}$. The free-floating coronal sections were washed three times (10 min each time) in $0.02 \mathrm{M}$ PBS, pH 7.4. To eliminate endogenous peroxidase activity, the sections were treated with $1 \% \mathrm{H}_{2} \mathrm{O}_{2}$ in $\mathrm{H}_{2} \mathrm{O}$ for $15-30$ min and then rinsed six times in 0.02 PBS. To block non-specific binding, the sections were incubated in a solution containing $10 \%$ normal goat serum (Colorado Serum Co., Denver, CO, USA, \#CS 0922) and 0.3\% Triton X-100 in 0.02 M PBS for $2 \mathrm{~h}$ at room temperature. After that, the sections were incubated in a solution containing rabbit anti-5- $\mathrm{HT}_{2 \mathrm{~A}} \mathrm{R}$ polyclonal antibody (diluted 1:300; code 24288; ImmunoStar, Hudson, WI, USA), 0.3\% 
Triton X-100, and $1 \%$ normal goat serum for $48 \mathrm{~h}$ at $4{ }^{\circ} \mathrm{C}$. Following incubation in the primary antiserum, the sections were washed three times (10 min each) in 0.02M PBS containing $2 \%$ normal goat serum. Successively, the sections were incubated in a solution containing goat biotinylated anti-rabbit (1:200, Vector, Burlingame, CA, USA, BA-1000), 1\% normal goat serum and $0.3 \%$ Triton X-100 in 0.02M PBS, $\mathrm{pH} 7.4$ for $60 \mathrm{~min}$ at room temperature. The sections were washed three times for $10 \mathrm{~min}$ each in $0.02 \mathrm{M}$ PBS containing 2\% normal goat serum and were then transferred to avidin-biotin complex (ABC kit Vectastain, PK-6100, Vector Laboratories, Burlingame, CA, USA) for $45 \mathrm{~min}$. The immunoperoxidase reaction was developed by 3.3'-diaminobenzidine (DAB kit, SK-4100, Vector Laboratories, Burlingame, CA, USA). After washing, the sections were mounted onto gelatin-coated slides, dried overnight at $37^{\circ} \mathrm{C}$, defatted and intensified, according to a previous study [64], with $\mathrm{OsO} 4(0.005 \%$, Electron Microscopy Sciences, \#19130, Ft. Washington, PA, USA) and thiocarbohydrazide (0.05\%, Electron Microscopy Sciences, \#21900), and coverslipped with Entellan (Merck, Darmstadt, Germany).

\subsection{Double Immunofluorescence Experiments}

Double immunostaining was performed on the LHb, NAc, VTA, DRN, DG, SNc, ST, and mPFC. Preliminary experiments were carried out to determine the optimal fixative mixture to be used in the double immunofluorescence methods. The final concentrations of primary antibodies were established by performing double immunofluorescence experiments using different dilution patterns. Whole, free-floating coronal sections were washed three times (10 min each) in PBS. To block non-specific binding, the sections were incubated in 10\% normal goat serum (Colorado Serum Co., Denver, CO, USA, \#CS 0922) and 0.3\% Triton X-100 in $0.02 \mathrm{M}$ PBS for $40 \mathrm{~min}$ at room temperature. After that, the sections were washed three times (10 min each) in a solution containing $1 \%$ normal goat serum and $0.3 \%$ Triton X-100 in 0.02 M PBS. For colocalization studies, the sections were incubated for 2 days at $4{ }^{\circ} \mathrm{C}$ in a mixture of primary antibodies: (a) rabbit anti-5- $\mathrm{HT}_{2 \mathrm{~A}} \mathrm{R}$ polyclonal antibody (diluted 1:300; code 24288; ImmunoStar, WI, USA) together with mouse anti-HuC/D monoclonal antibody (diluted 1:200; code A21271; Molecular Probes, Leiden, the Netherlands), which were dissolved in 1\% normal goat serum (Colorado Serum Co., Denver, CO, USA, \#CS 0922) and 0.3\% Triton X-100 in 0.02 M PBS. The sections were washed three times as described before and incubated overnight in a secondary antibody solution containing Alexa 488-conjugated goat anti-mouse IgG (1:400, \#A11029, Molecular Probes, Leiden, the Netherlands), Alexa 594-conjugated goat anti-rabbit IgG (1:400, \#A11012, Molecular Probes, Leiden, the Netherlands), $1 \%$ normal goat serum, and $0.3 \%$ Triton X-100 in $0.02 \mathrm{M}$ PBS. The sections were then washed with 0.02 M PBS and mounted on glass microscope slides (Super Frost Plus, Menzel-Glaser \#J1800AMNZ), dried, and coverslipped using Vectashield Mounting Medium (\#H-1000, Vector Laboratories, Burlingame, CA, USA).

\subsection{Specificity of Antibodies}

Rabbit polyclonal antibody anti-5- $\mathrm{HT}_{2 \mathrm{~A}} \mathrm{R}$ is directed against an $\mathrm{N}$-terminal synthetic sequence corresponding to amino acids $22-41$ of rat $5-\mathrm{HT}_{2 \mathrm{~A}} \mathrm{R}$. The specificity of this antibody was determined in pre-adsorption tests and Western blot studies conducted by the manufacturer and in immunohistochemical studies $[65,66]$. In the present experiments, control sections incubated without the primary antibody resulted in a complete disappearance of stained profiles. The specificity of mouse anti-HuC/D monoclonal antibody (code A21271; Molecular Probes) has previously been confirmed by blocking antibody-binding with the specific peptide [67]. The omission, as well as the replacement of the secondary antibodies with inappropriate secondary antibodies, resulted in the elimination of all immunohistochemical staining.

\subsection{Thionin Staining}

To help identify the boundaries of the LHb, NAcc, VTA, DRN, DG, SNp, ST, and mPFC sections adjacent to immunolabelled sections were stained with thionin as follows. Sections were taken out of the $10 \%$ formaldehyde solution, mounted on gelatin-coated slides and dried overnight at $37^{\circ} \mathrm{C}$. 
Sections were defatted $1 \mathrm{~h}$ in a mixture of chloroform/ethanol 100\% (1:1), and then rehydrated through a graded series of ethanol, $2 \times 2 \mathrm{~min}$ in 100\% ethanol, $2 \mathrm{~min}$ in $96 \%$ ethanol, $2 \mathrm{~min}$ in $70 \%$ ethanol, $2 \mathrm{~min}$ in $50 \%$ ethanol, $2 \mathrm{~min}$ in $\mathrm{dH}_{2} \mathrm{O}$, and stained $30 \mathrm{~s}$ in a $0.125 \%$ thionin (Fisher Scientific, Loughborough, UK) solution, dehydrated, and coverslipped with Entellan (Merck, Darmstadt, Germany).

\subsection{Analysis of Sections}

\subsubsection{Immunoperoxidase Experiments}

Sections were analyzed using a Leica DMRB microscope. Brightfield images were acquired using a Polaroid DMC digital camera (Polaroid Corporation, Cambridge, MA, USA) and DMC 2 software. Contrast and brightness were adjusted to reflect the appearance of the labeling seen through the microscope using Adobe Photoshop CS3 Extended 10.0 software (Adobe Systems, San Jose, CA, USA).

To calculate the density of 5- $\mathrm{HT}_{2 \mathrm{~A}} \mathrm{R}-\mathrm{IR}$ neurons, immunostained somata were plotted bilaterally in every fifth section throughout the LHb with a computer-aided digitizing system (Accustage 5.1, St. Shoreview, MN, USA). The boundaries of the LHb were drawn from the adjacent thionin-stained sections using a stereomicroscope equipped with a drawing tube. The outlines were superimposed on computer generating plots using Corel Draw X3 (Corel Corporation, Ottawa, Ontario, Canada). The area measurements were done from the line drawings by using AxioVision Rel.4.8 (Zeiss). The density of immunostained neurons was calculated as the number of somata/ $/ \mathrm{mm}^{2}$ in each section separately. For each rat, the left and right LHb located in 5 sections were analyzed. The neuronal counts are expressed as the mean number of somata $/ \mathrm{mm}^{2} \pm$ standard deviation and the data from the nicotine-naïve, acute nicotine, chronic nicotine were compared.

\subsubsection{Double Immunofluorescence Experiments}

Double immunofluorescence sections were analyzed with a Nikon H550L (Nikon Instruments, Tokyo, Japan) equipped with the appropriate filter cubes for immunofluorescence. We used the FITC filter for Alexa 488 (Ex 465-495; DM 505; BA 515-555) and the TRITC filter for Alexa 594 (EX 540/25; DM 565; BA 605-655). For immunofluorescence analysis, the neurons were first located by the presence of a fluorophore, which labeled one antigen, and the filter was then switched to a fluorophore specific for a different wavelength to determine whether or not the neuron was labeled for a second antigen. In this way, the proportions of neurons labeled for pairs of antigens or a single antigen were determined. Bilateral colocalization studies were assessed at the various rostrocaudal levels of the LHb. In particular, counts of single- and double-labeled neurons were carried out in five non-consecutive sections obtained from the right and left LHb, NAc, VTA, DRN, DG, SNc, ST, and $\mathrm{mPFC}$ of each rat. Data concerning the percentage of the image covered by $5-\mathrm{HT}_{2 \mathrm{~A}} \mathrm{R}$ immunoreactivity were obtained using the automatic threshold algorithm of ImageJ (version IJ 1.46r downloaded from http://imagej.nih.gov/ij/download.html). For this analysis, images were taken using a Nikon H550L (Nikon Instruments, Tokyo, Japan) microscope under identical acquisition parameters from naïve nicotine, acute nicotine and chronic nicotine. For each animal, five sections were analyzed. The images were recorded using a Nikon-Qi1Mc photo camera (Nikon Instruments, Japan) and Nikon Elements Version 4.10 software. The contrast and brightness of the figures were adjusted to reflect the appearance of the labeling seen through the microscope using Adobe Photoshop CS3 Extended 10.0 software (Adobe Systems, San Jose, CA, USA).

\subsection{Electrophysiological Recordings}

\subsubsection{Extracellular Single-Unit Recordings}

Rats were anesthetized with chloral hydrate ( $400 \mathrm{mg} / \mathrm{kg}$, i.p., Sigma-Aldrich, UK) and anesthesia was maintained with a continuous intravenous (i.v.) infusion of chloral hydrate $(8 \% w / v ; 8 \mathrm{~mL} / \mathrm{h})$. Standard single-unit extracellular recording of LHb neurons was performed as described previously [34]. 
Micropipettes (4-7 $\mathrm{M} \Omega$ resistance) were positioned in the $\mathrm{LHb}$ (set at a $10^{\circ}$ angle, $3.4-3.8 \mathrm{~mm}$ anteroposterior from bregma, 1.4-1.8 $\mathrm{mm}$ mediolateral from the midline, 4-5 $\mathrm{mm}$ dorsoventral from the cortical surface) [68]. Signal acquisition was made with a micro1401 CED laboratory interface connected to Spike2 v7.4 (Cambridge Electronic Design, Cambridge, UK) and a Neurolog amplifier and filtering system (Digitimer Ltd. UK; 10k amplification, bandpass filter set at $0.5-5 \mathrm{kHz}$ ). The location of the recording site was confirmed with histological analysis.

\subsubsection{Drugs and Pharmacological Treatments}

TCB-2 ((4-Bromo-3,6-dimethoxybenzocyclobuten-1-yl)methylamine hydrobromide) and nicotine ((-)-Nicotine hydrogen tartrate salt, (-)-1-Methyl-2-(3-pyridyl) pyrrolidine (+)-bitartrate salt) were purchased from Tocris Biosciences, UK, and Sigma Aldrich, St. Louis, MO, USA, respectively and dissolved as previously described $[29,34,69]$. The doses have been chosen based on previous experiments reporting their efficacy and selectivity [29,32,34,69-72]. All laboratory reagents were purchased from Sigma-Aldrich, Gillingham, UK.

Rats from acute or chronic nicotine-treated $(6 \mathrm{mg} / \mathrm{kg} /$ day for fourteen days) groups were treated with a challenge dose of $2 \mathrm{mg} / \mathrm{kg}$, i.p. of nicotine or its vehicle (saline) one h before the recording of neurons. Once a stable neuron was detected using the procedure previously described, the rat was given i.v. through the lateral tail vein $640 \mu \mathrm{g} / \mathrm{kg}$ cumulative doses of TCB-2 or its vehicle. A total of eight doses $(5,5,10,20,40,80,160$ and $320 \mu \mathrm{g} / \mathrm{kg})$, each dissolved in $100 \mu \mathrm{L}$ of the vehicle were given at two-minute intervals.

The average firing rate ( $\left.\mathrm{FR}_{\text {baseline }}\right)$ from the initial $10 \mathrm{~min}$ baseline recording was used to normalize the data for subsequent time points $\left(\mathrm{FR}_{\mathrm{x}}\right)$, i.e., the $2 \mathrm{~min}$ following each of the eight cumulative agonist doses. Firing activity was expressed as the percentage change in firing for each time point with the baseline firing: $\left(\frac{F R_{x}-F R_{\text {baseline }}}{F R_{\text {baseline }}}\right) \times 100$. If two-time points recorded a $20 \%$ increase or a $20 \%$ decrease in neuronal activity, or none of the above, the LHb neuron was classified belonging to the increase, decrease, or null group, respectively, according to published criteria [34].

\subsection{Statistical Analysis}

The data report the mean \pm SEM for each group if any. One-way ANOVA with repeated measures was performed separately for each treatment group compared to their respective controls. It was followed by Tukey post-hoc test (if required). A significant difference was considered when $p<0.05$.

Supplementary Materials: Supplementary materials can be found at http://www.mdpi.com/1422-0067/21/5/1873/ s1.

Author Contributions: Conceptualization, F.D., M.P. and G.D.G.; methodology G.D., M.C., P.D.D., G.D.G.; formal analysis, C.B., F.D., C.T., M.P., and G.D.G.; investigation, C.B., F.D.; resources, C.B. and G.D.G.; data curation, C.B., F.D., C.T., M.C., P.D.D., M.P. and G.D.G.; writing-original draft preparation, C.B. and G.D.G.; writing-review and editing, P.D.D., G.D.G.; supervision, C.B. and G.D.G.; project administration, G.D.G.; funding acquisition, C.B. and G.D.G. All authors have read and agreed to the published version of the manuscript.

Funding: This research was funded by the University of Malta, Internal Research Grant scheme and G.D., M.P. were supported by a fellowship of the Faculty of Medicine, University of Malta.

Conflicts of Interest: The authors declare no conflict of interest.

\section{Abbreviations}

$\begin{array}{ll}( \pm)-\mathrm{DOI} & \text { 2,5-dimethoxy-4-iodoamphetamine } \\ 5-\mathrm{HT} & 5 \text {-hydroxytryptamine } \\ 5-\mathrm{HT}_{2 \mathrm{C}} \mathrm{Rs} & 5-\mathrm{HT}_{2 \mathrm{C}} \text { receptors } \\ 5-\mathrm{HT}_{\mathrm{A}} \mathrm{Rs} & 5-\mathrm{HT}_{\mathrm{A}} \text { receptors } \\ \mathrm{AN} & \text { Acute nicotine } \\ \mathrm{CN} & \text { Chronic nicotine }\end{array}$




$\begin{array}{ll}\text { DA } & \text { Dopamine } \\ \text { DG } & \text { dentate gyrus } \\ \text { DRN } & \text { dorsal raphe nucleus } \\ \text { GABA } & \text { Gamma-aminobutyric acid } \\ \text { GLU } & \text { Glutamate }_{\text {HT2A }} \\ \text { IHC } & \text { immun }_{\text {A }} \text { receptor gene } \\ \text { mPFC } & \text { Medial prefrontal cortex } \\ \text { NAc } & \text { nucleus accumbens } \\ \text { nAChRs } & \text { Nicotinic cholinergic receptors } \\ \text { NN } & \text { Naïve nicotine } \\ \text { PBS } & \text { phosphate-buffered saline } \\ \text { SNc } & \text { substantia nigra pars compacta } \\ \text { ST } & \text { Striatum } \\ \text { TCB-2 } & \text { (4-Bromo-3,6-dimethoxybenzocyclobuten-1-yl)methylamine hydrobromide } \\ \text { VTA } & \text { Ventral tegmental area }\end{array}$

\section{References}

1. WHO. WHO Report on the Global Tobacco Epidemic 2017. 2017, WHO/NMH/PND/17.4. Available online: https://www.who.int/tobacco/global_report/2017/en/ (accessed on 6 March 2020).

2. Leone, A.; Landini, L.; Leone, A. What is Tobacco Smoke? Sociocultural Dimensions of the Association with Cardiovascular Risk. Curr. Pharm. Des. 2010, 16, 2510-2517. [CrossRef]

3. Office on Smoking and Health. Surgeon General's Report: The Health Consequences of Smoking-50 Years of Progress. Available online: https://www.cdc.gov/tobacco/data_statistics/sgr/50th-anniversary/index.htm (accessed on 20 May 2019).

4. Di Giovanni, G. Nicotine Addiction: Prevention, Health Effects and Treatment Options; Nova Science Publishers: New York, NT, USA, 2012; pp. 1-283.

5. Rose, J.E. Nicotine and nonnicotine factors in cigarette addiction. Psychophamacology (Berl.) 2006, 184, $274-285$. [CrossRef] [PubMed]

6. Stolerman, I.P.; Jarvis, M.J. The scientific case that nicotine is addictive. Psychopharmacology (Berl.) 1995, 117, 2-10. [CrossRef] [PubMed]

7. Di Matteo, V.; Pierucci, M.; Di Giovanni, G.; Benigno, A.; Esposito, E. The neurobiological bases for the pharmacotherapy of nicotine addiction. Curr. Pharm. Des. 2007, 13, 1269-1284. [CrossRef] [PubMed]

8. Corrigall, W.A.; Franklin, K.B.; Coen, K.M.; Clarke, P.B. The mesolimbic dopaminergic system is implicated in the reinforcing effects of nicotine. Psychopharmacology 1992, 107, 285-289. [CrossRef] [PubMed]

9. Di Chiara, G. Role of dopamine in the behavioural actions of nicotine related to addiction. Eur. J. Pharmacol. 2000, 393, 295-314. [CrossRef]

10. Alasmari, F.; Al-Rejaie, S.S.; AlSharari, S.D.; Sari, Y. Targeting glutamate homeostasis for potential treatment of nicotine dependence. Brain Res. Bull. 2016, 121, 1-8. [CrossRef]

11. Di Matteo, V.; Pierucci, M.; Benigno, A.; Esposito, E.; Crescimanno, G.; Di Giovanni, G. Critical role of nitric oxide on nicotine-induced hyperactivation of dopaminergic nigrostriatal system: Electrophysiological and neurochemical evidence in rats. CNS Neurosci. Ther. 2010, 16, 127-136. [CrossRef]

12. D'Souza, M.S.; Markou, A. The "stop" and "go" of nicotine dependence: role of GABA and glutamate. Cold Spring Harb. Perspect. Med. 2013, 3. [CrossRef]

13. Lester, R.J. Nicotinic Receptors; Springer International Publishing: New York, NY, USA, 2014; pp. 1-461.

14. Pierucci, M.; Di Matteo, V.; Esposito, E. Stimulation of Serotonin2C Receptors Blocks the Hyperactivation of Midbrain Dopamine Neurons Induced by Nicotine Administration. J. Pharmacol. Exp. Ther. 2004, 309, 109-118. [CrossRef]

15. Grottick, A.J.; Corrigall, W.A.; Higgins, G.A. Activation of 5-HT(2C) receptors reduces the locomotor and rewarding effects of nicotine. Psychopharmacology 2001, 157, 292-298. [CrossRef] [PubMed]

16. Higgins, G.A.; Fletcher, P.J. Therapeutic Potential of 5-HT2C Receptor Agonists for Addictive Disorders. ACS Chem. Neurosci. 2015, 6, 1071-1088. [CrossRef] [PubMed] 
17. Pierucci, M.; Chambers, S.; Partridge, L.; De Deurwaerdère, P.; Di Giovanni, G. Role of central serotonin receptors in nicotine addiction. In Nicotinic Receptors; Springer International Publishing: New York, NY, USA, 2014; pp. 279-305.

18. De Deurwaerdere, P.; Di Giovanni, G. Serotonergic modulation of the activity of mesencephalic dopaminergic systems: Therapeutic implications. Prog. Neurobiol. 2017, 151, 175-236. [CrossRef] [PubMed]

19. Di Giovanni, G.; De Deurwaerdere, P.; Di Mascio, M.; Di Matteo, V.; Esposito, E.; Spampinato, U. Selective blockade of serotonin-2C/2B receptors enhances mesolimbic and mesostriatal dopaminergic function: a combined in vivo electrophysiological and microdialysis study. Neuroscience 1999, 91, 587-597. [CrossRef]

20. Fletcher, P.J.; Rizos, Z.; Noble, K.; Soko, A.D.; Silenieks, L.B.; Lê, A.D.; Higgins, G.A. Effects of the 5-HT2C receptor agonist Ro60-0175 and the 5-HT2A receptor antagonist M100907 on nicotine self-administration and reinstatement. Neuropharmacology 2012, 62, 2288-2298. [CrossRef]

21. Zaniewska, M.; McCreary, A.C.; Wydra, K.; Filip, M. Effects of serotonin (5-HT) 2 receptor ligands on depression-like behavior during nicotine withdrawal. Neuropharmacology 2010, 58, 1140-1146. [CrossRef]

22. Rose, J.E.; Behm, F.M.; Salley, A.N.; Bates, J.E.; Coleman, R.E.; Hawk, T.C.; Turkington, T.G. Regional brain activity correlates of nicotine dependence. Neuropsychopharmacology 2007, 32, 2441. [CrossRef]

23. Bombardi, C. Brain Distribution. In 5-HT2A Receptors in the Central Nervous System; Guiard, B.P., Di Giovanni, G., Eds.; Springer International Publishing: New York, NY, USA, 2018; pp. 67-84.

24. Zaniewska, M.; McCreary, A.C.; Wydra, K.; Faron-Górecka, A.; Filip, M. Context-controlled nicotine-induced changes in the labeling of serotonin (5-HT)2A and 5-HT2C receptors in the rat brain. Pharmacol. Rep. 2015, 67, 451-459. [CrossRef]

25. Bianco, I.H.; Wilson, S.W. The habenular nuclei: a conserved asymmetric relay station in the vertebrate brain. Philos. Trans. R. Soc. Lond. 2009, 364, 1005-1020. [CrossRef]

26. Pierucci, M.; Pitruzzella, A.; Valentino, M.; Zammit, C.; Muscat, R.; Benigno, A.; Di Giovanni, G. Lateral Habenula contribution in nicotine addiction: Focus on dopamine, GABA and serotonin interactions. Malta Medical Journal 2011, 23, 28-32.

27. Dao, D.Q.; Perez, E.E.; Teng, Y.; Dani, J.A.; De Biasi, M. Nicotine enhances excitability of medial habenular neurons via facilitation of neurokinin signaling. J. Neurosci. 2014, 34, 4273-4284. [CrossRef] [PubMed]

28. Velasquez, K.M.; Molfese, D.L.; Salas, R. The role of the habenula in drug addiction. Front. Hum. Neurosci. 2014, 8. [CrossRef] [PubMed]

29. Casarrubea, M.; Davies, C.; Faulisi, F.; Pierucci, M.; Colangeli, R.; Partridge, L.; Chambers, S.; Cassar, D.; Valentino, M.; Muscat, R.; et al. Acute nicotine induces anxiety and disrupts temporal pattern organization of rat exploratory behavior in hole-board: A potential role for the lateral habenula. Front. Cell. Neurosci. 2015, 9. [CrossRef] [PubMed]

30. Metzger, M.; Bueno, D.; Lima, L.B. The lateral habenula and the serotonergic system. Pharmacol. Biochem. Behav. 2017, 162, 22-28. [CrossRef]

31. Tchenio, A.; Valentinova, K.; Mameli, M. Can the Lateral Habenula Crack the Serotonin Code? Front. Synaptic Neurosci. 2016, 8, 34. [CrossRef]

32. Di Giovanni, G.; De Deurwaerdere, P. TCB-2 [(7R)-3-bromo-2, 5-dimethoxy-bicyclo[4.2.0]octa-1,3,5-trien-7-yl]methanamine]: A hallucinogenic drug, a selective 5-HT2A receptor pharmacological tool, or none of the above? Neuropharmacology 2017. [CrossRef]

33. McLean, T.H.; Parrish, J.C.; Braden, M.R.; Marona-Lewicka, D.; Gallardo-Godoy, A.; Nichols, D.E. 1-Aminomethylbenzocycloalkanes: conformationally restricted hallucinogenic phenethylamine analogues as functionally selective 5-HT2A receptor agonists. J. Med. Chem. 2006, 49, 5794-5803. [CrossRef]

34. Delicata, F.; Bombardi, C.; Pierucci, M.; Di Maio, R.; De Deurwaerdere, P.; Di Giovanni, G. Preferential modulation of the lateral habenula activity by serotonin-2A rather than $-2 \mathrm{C}$ receptors: Electrophysiological and neuroanatomical evidence. CNS Neurosci.Ther. 2018, 24, 721-733. [CrossRef]

35. Fletcher, P.J.; Le, A.D.; Higgins, G.A. Serotonin receptors as potential targets for modulation of nicotine use and dependence. Prog. Brain Res. 2008, 172, 361-383. [CrossRef]

36. Hernandez-Lopez, S.; Garduno, J.; Mihailescu, S. Nicotinic modulation of serotonergic activity in the dorsal raphe nucleus. Rev. Neurosci. 2013, 24, 455-469. [CrossRef] 
37. Wagner, F.; Bernard, R.; Derst, C.; French, L.; Veh, R.W. Microarray analysis of transcripts with elevated expressions in the rat medial or lateral habenula suggest fast GABAergic excitation in the medial habenula and habenular involvement in the regulation of feeding and energy balance. Brain Struct. Funct. 2016, 221, 4663-4689. [CrossRef] [PubMed]

38. Rasmussen, K.; Czachura, J.F. Nicotine withdrawal leads to increased sensitivity of serotonergic neurons to the 5-HT1A agonist 8-OH-DPAT. Psychopharmacology (Berl) 1997, 133, 343-346. [CrossRef] [PubMed]

39. Sperling, R.; Commons, K.G. Shifting topographic activation and 5-HT1A receptor-mediated inhibition of dorsal raphe serotonin neurons produced by nicotine exposure and withdrawal. J. Neurosci. 2011, 33, 1866-1875. [CrossRef] [PubMed]

40. Zuo, W.; Xiao, C.; Gao, M.; Hopf, F.W.; Krnjevic, K.; McIntosh, J.M.; Fu, R.; Wu, J.; Bekker, A.; Ye, J.H. Nicotine regulates activity of lateral habenula neurons via presynaptic and postsynaptic mechanisms. Sci. Rep. 2016, 6, 32937. [CrossRef]

41. Xie, G.; Zuo, W.; Wu, L.; Li, W.; Wu, W.; Bekker, A.; Ye, J.-H. Serotonin modulates glutamatergic transmission to neurons in the lateral habenula. Sci. Rep. 2016, 6, 23798. [CrossRef]

42. Zuo, W.; Zhang, Y.; Xie, G.; Gregor, D.; Bekker, A.; Ye, J.H. Serotonin stimulates lateral habenula via activation of the post-synaptic serotonin $2 / 3$ receptors and transient receptor potential channels. Neuropharmacology 2016, 101, 449-459. [CrossRef]

43. Singer, S.; Rossi, S.; Verzosa, S.; Hashim, A.; Lonow, R.; Cooper, T.; Sershen, H.; Lajtha, A. Nicotine-induced changes in neurotransmitter levels in brain areas associated with cognitive function. Neurochem.Res. 2004, 29, 1779-1792. [CrossRef]

44. Cornea-Hebert, V.; Riad, M.; Wu, C.; Singh, S.K.; Descarries, L. Cellular and subcellular distribution of the serotonin 5-HT2A receptor in the central nervous system of adult rat. J. Comp. Neurol. 1999, 409, 187-209. [CrossRef]

45. Leysen, J.E.; Eens, A.; Gommeren, W.; van Gompel, P.; Wynants, J.; Janssen, P.A. Identification of nonserotonergic $[3 \mathrm{H}]$ ketanserin binding sites associated with nerve terminals in rat brain and with platelets; relation with release of biogenic amine metabolites induced by ketanserin- and tetrabenazine-like drugs. J. Pharmacol. Exp. Ther. 1988, 244, 310-321.

46. Miguelez, C.; Morera-Herreras, T.; De Deurwaerdère, P. 5-HT2A receptors in the Basal Ganglia. In 5-HT2A Receptors in the Central Nervous System; Guiard, B., Di Giovanni, G., Eds.; Springer International Publishing: New York, NY, USA, 2018; Volume 32, pp. 273-310.

47. Graziane, N.M.; Neumann, P.A.; Dong, Y. A Focus on Reward Prediction and the Lateral Habenula: Functional Alterations and the Behavioral Outcomes Induced by Drugs of Abuse. Front. Synaptic Neurosci 2018, 10. [CrossRef]

48. Lecca, S.; Melis, M.; Luchicchi, A.; Ennas, M.G.; Castelli, M.P.; Muntoni, A.L.; Pistis, M. Effects of drugs of abuse on putative rostromedial tegmental neurons, inhibitory afferents to midbrain dopamine cells. Neuropsychopharmacology 2011, 36, 589-602. [CrossRef] [PubMed]

49. Fowler, C.D.; Kenny, P.J. Nicotine aversion: Neurobiological mechanisms and relevance to tobacco dependence vulnerability. Neuropharmacology 2014, 76, 533-544. [CrossRef] [PubMed]

50. Olausson, P.; Akesson, P.; Engel, J.A.; Soderpalm, B. Effects of 5-HT1A and 5-HT2 receptor agonists on the behavioral and neurochemical consequences of repeated nicotine treatment. Eur. J. Pharmacol. 2001, 420, 45-54. [CrossRef]

51. Batman, A.M.; Munzar, P.; Beardsley, P.M. Attenuation of nicotine's discriminative stimulus effects in rats and its locomotor activity effects in mice by serotonergic 5-HT2A/2C receptor agonists. Psychopharmacology (Berl) 2005, 179, 393-401. [CrossRef] [PubMed]

52. Zaniewska, M.; McCreary, A.C.; Przegalinski, E.; Filip, M. Effects of the serotonin 5-HT2A and 5-HT2C receptor ligands on the discriminative stimulus effects of nicotine in rats. Eur. J. Pharmacol. 2007, 571, 156-165. [CrossRef]

53. Levin, E.; Icenogle, L.; Farzad, A. Ketanserin attenuates nicotine-induced working memory improvement in rats. Pharmacol. Biochem. Behav. 2005, 82, 289-292. [CrossRef]

54. Rezvani, A.H.; Caldwell, D.P.; Levin, E.D. Nicotinic-serotonergic drug interactions and attentional performance in rats. Psychopharmacology 2005, 179, 521-528. [CrossRef] 
55. Zaniewska, M.; McCreary, A.C.; Wydra, K.; Filip, M. Differential effects of serotonin (5-HT)2 receptor-targeting ligands on locomotor responses to nicotine-repeated treatment. Synapse (New York, N.Y.) 2010, 64, 511-519. [CrossRef]

56. Kutlu, M.G.; Gould, T.J. Nicotinic modulation of hippocampal cell signaling and associated effects on learning and memory. Physiol. Behav. 2016, 155, 162-171. [CrossRef]

57. Meneses, A. 5-HT systems: emergent targets for memory formation and memory alterations. Rev. Neurosci. 2013, 24, 629-664. [CrossRef]

58. Bombardi, C.; Di Giovanni, G. Functional anatomy of 5-HT2A receptors in the amygdala and hippocampal complex: relevance to memory functions. Exp. Brain Res. 2013, 230, 427-439. [CrossRef] [PubMed]

59. Afshar, S.; Shahidi, S.; Rohani, A.H.; Komaki, A.; Asl, S.S. The effect of NAD-299 and TCB-2 on learning and memory, hippocampal BDNF levels and amyloid plaques in Streptozotocin-induced memory deficits in male rats. Psychopharmacology 2018, 235, 2809-2822. [CrossRef] [PubMed]

60. Zhang, G.; Asgeirsdottir, H.N.; Cohen, S.J.; Munchow, A.H.; Barrera, M.P.; Stackman, R.W., Jr. Stimulation of serotonin $2 \mathrm{~A}$ receptors facilitates consolidation and extinction of fear memory in C57BL/6J mice. Neuropharmacology 2013, 64, 403-413. [CrossRef] [PubMed]

61. Bekinschtein, P.; Renner, M.C.; Gonzalez, M.C.; Weisstaub, N. Role of medial prefrontal cortex serotonin 2A receptors in the control of retrieval of recognition memory in rats. J. Neurosci. 2013, 33, 15716-15725. [CrossRef] [PubMed]

62. Malin, D.; Henceroth, M.; Rao, G.S.; Campbell, J.; Ma, J.-N.; Tsai, P.-H.; Kishbaugh, J.C.; Burstein, E.S. Inverse agonists of the 5-HT2A receptor reduce nicotine withdrawal signs in rats. Neurosci. Lett. 2019, 713, 134524. [CrossRef]

63. Zaniewska, M.; Alenina, N.; Wydra, K.; Frohler, S.; Kusmider, M.; McCreary, A.C.; Chen, W.; Bader, M.; Filip, M. Discovering the mechanisms underlying serotonin (5-HT)2A and 5-HT2C receptor regulation following nicotine withdrawal in rats. J. Neurochem. 2015, 134, 704-716. [CrossRef]

64. Lewis, D.A.; Campbell, M.J.; Morrison, J.H. An immunohistochemical characterization of somatostatin-28 and somatostatin-281-12 in monkey prefrontal cortex. J. Comp. Neurol. 1986, 248, 1-18. [CrossRef]

65. Weber, E.T.; Andrade, R. Htr2a Gene and 5-HT(2A) Receptor Expression in the Cerebral Cortex Studied Using Genetically Modified Mice. Front. Neurosci. 2010, 4, 36. [CrossRef]

66. Nocjar, C.; Alex, K.D.; Sonneborn, A.; Abbas, A.I.; Roth, B.L.; Pehek, E.A. Serotonin-2C and -2a receptor co-expression on cells in the rat medial prefrontal cortex. Neuroscience 2015, 297, 22-37. [CrossRef]

67. Marusich, M.F.; Furneaux, H.M.; Henion, P.D.; Weston, J.A. Hu neuronal proteins are expressed in proliferating neurogenic cells. J. Neurobiol. 1994, 25, 143-155. [CrossRef]

68. Paxinos, G.; Watson, C. The Rat Brain in Stereotaxic Coordinates, 6th ed.; Academic Press: New York, NY, USA, 2007; p. 456.

69. Casarrubea, M.; Pierucci, M.; Aiello, S.; Cassar, D.; Deidda, G.; Crescimanno, G.; Di Giovanni, G. Effects of chronic nicotine on the temporal structure of anxiety-related behavior in rats tested in hole-board. Prog. Neuropsychopharmacol. Biol. Psychiatry 2019. [CrossRef] [PubMed]

70. Di Giovanni, G.; De Deurwaerdere, P. New therapeutic opportunities for 5-HT2C receptor ligands in neuropsychiatric disorders. Pharmacol. Ther. 2016, 157, 125-162. [CrossRef] [PubMed]

71. Venzi, M.; David, F.; Bellet, J.; Cavaccini, A.; Bombardi, C.; Crunelli, V.; Di Giovanni, G. Role for serotonin2A (5-HT2A) and 2C (5-HT2C) receptors in experimental absence seizures. Neuropharmacology 2016, 108, 292-304. [CrossRef] [PubMed]

72. Invernizzi, R.W.; Pierucci, M.; Calcagno, E.; Di Giovanni, G.; Di Matteo, V.; Benigno, A.; Esposito, E. Selective activation of 5- $\mathrm{HT}(2 \mathrm{C})$ receptors stimulates GABA-ergic function in the rat substantia nigra pars reticulata: A combined in vivo electrophysiological and neurochemical study. Neuroscience 2007, 144, 1523-1535. [CrossRef] [PubMed]

(C) 2020 by the authors. Licensee MDPI, Basel, Switzerland. This article is an open access article distributed under the terms and conditions of the Creative Commons Attribution (CC BY) license (http://creativecommons.org/licenses/by/4.0/). 